\title{
Asserting Human Rights Against Multinational Corporations Under United States Law: Conceptual and Procedural Problems
}

Phillip Blumberg

University of Connecticut School of Law

Follow this and additional works at: https://opencommons.uconn.edu/law_papers

Part of the Business Organizations Law Commons, and the Comparative and Foreign Law Commons

\section{Recommended Citation}

Blumberg, Phillip, "Asserting Human Rights Against Multinational Corporations Under United States Law: Conceptual and Procedural Problems" (2002). Faculty Articles and Papers. 387.

https://opencommons.uconn.edu/law_papers/387 


\section{HEINONLINE}

Citation:

Philip I. Blumberg, Asserting Human Rights against

Multinational Corporations under United States Law:

Conceptual and Procedural Problems, 50 Am. J. Comp. L.

Supp. 493 (2002)

Content downloaded/printed from $\underline{\text { HeinOnline }}$

Thu Jun 21 14:33:20 2018

-- Your use of this HeinOnline PDF indicates your acceptance of HeinOnline's Terms and Conditions of the license agreement available at https://heinonline.org/HOL/License

-- The search text of this PDF is generated from uncorrected OCR text.

-- To obtain permission to use this article beyond the scope of your HeinOnline license, please use:

\section{Copyright Information}

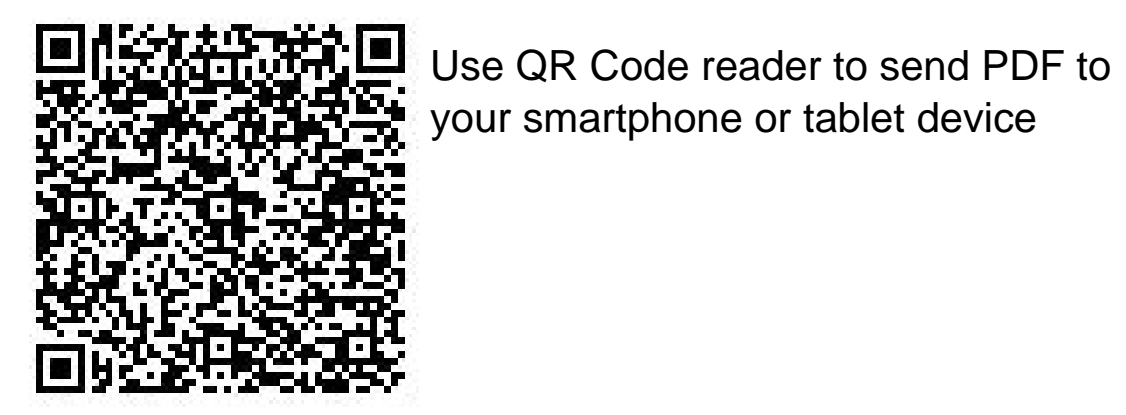




\section{PHILLIP I. BLUMBERG}

\section{Asserting Human Rights Against Multinational Corporations Under United States Law: Conceptual and Procedural Problems}

\section{INTRODUCTION}

This paper reviews the conceptual and procedural problems under American law presented by the growing tide of litigation involving the assertion of claims against American parent corporations of multinational groups for alleged violations of international human rights abroad in the conduct of their global enterprises. These cases involve conduct in other countries allegedly injuring foreign nationals. In almost all the reported cases, the conceptual and procedural hurdles to trial in the United States have effectively blocked a hearing of the cases in the United States. This paper explores how the existing body of American law in these areas has led to such an outcome. In addition to such problems, this body of litigation also involves serious substantive issues. These are beyond the scope of this paper and are reviewed in the paper of United States co-reporter, Professor Stephen Wood.

\section{Corporate Groups and Traditional Concepts of the CORPORATE ENTITY}

In the modern global economy, the largest corporations conduct worldwide operations. They operate in the form of multinational corporate groups organized in "incredibly complex" multi-tiered corporate structures consisting of a dominant parent corporation, subholding companies, and scores or hundreds of subservient subsidiaries scattered around the world. The 1999 World Investment Report estimated that there are almost 60,000 multinational corporate groups with more than 500,000 foreign subsidiaries and affiliates. ${ }^{1}$

To the economists and the public, the multinational group is a single enterprise or firm. It is perceived as a single actor. This perception is accurate, supported by the common control, common busi-

Phillip I. Blumberg, A.B., Harvard; J.D. Harvard; LL.D. (hon.) The University of Connecticut. Dean and Professor of Law and Business, Emeritus, The University of Connecticut School of Law.

1. UNCTAD 1999 World Investment Report, UN Foreign Investment and the Challenge of Development (1999). 
ness purpose, economic integration, financial and even administrative interdependence, and often common public persona that characterize the group's operations. This is the economic reality. While each of the many group subsidiaries is typically incorporated under the laws of the nation in which it conducts business, the group has been given a popular national identity based on its historical origin and the state of incorporation of the parent company. ${ }^{2}$

\section{A. Traditional Concepts of the Corporate Entity}

The legal conceptualization is very different from the view of economists and the public. In the law of the United States as in the law of all Western countries, each of the constituent corporations of the group is regarded as a separate juridical person ${ }^{3}$ with its own legal rights and duties, separate and distinct from those of its shareholders. British Petroleum is not a single firm for legal purposes. It consists of more than one thousand separate interrelated corporations acting under common control. This is entity law. Resting on medieval concepts of Roman law, this view of the corporate legal personality is the foundation of the national corporation laws of every Western state. ${ }^{4}$ Similarly, under accepted principles of international law, each of the constituent corporations of a corporate group is a national of the nation-state in which it has been incorporated and subject to the laws of that state. ${ }^{5}$ In addition, this conceptual view of the corporate juridical entity is reinforced by a very different principle: the doctrine of limited liability of shareholders that is similarly accepted in all Western countries. ${ }^{6}$

This is well known. What has attracted little attention, however, is that these twin concepts -corporate personality and limited liability - were automatically applied to the constituent companies of corporate groups when groups first emerged in the American society. Until New Jersey radically revised by its corporation laws in 1890, corporations were not allowed to own shares of other corporations and thereby form corporate groups unless expressly authorized by the legislature. Although exceptions were made in the case of certain

2. With the increasing internationalization of corporate leadership, public investment, and acquisition policy, this popular identification may be in the early stage of a process of change. See Mabry, "Multinational Corporations and U.S. Technology Policy: Rethinking the Concept of Nationality," 87 Geo. L. J. 563 (1999).

3. See Case of Sutton's Hosp., 10 Coke 23a, 77 Eng. Rep. 960, 970-71, 973 (1612); $1 \mathrm{~W}$. Blackstone, Commentaries on the Law of England $467-68,470,472,478\left(1^{\text {st }} \mathrm{ed}\right.$. $1765)$.

4. See Phillip I. Blumberg, The Multinational Challenge to Corporation Law. The Search for a New Corporate Personality 3-5 (1993).

5. The Barcelona Traction Co., (Belgium v. Spain) I.C.J. 3 (1970). See Restatement (Third) of the Foreign Relations Law of the United Sates \$212 (1985).

6. See Blumberg, "Limited Liability and Corporate Groups," 11 J. Corp. L. 573, 577-99 (1986). 
railroads and telegraph companies, such authority was never granted to manufacturing corporations until New Jersey's breach of the principle. Previous doctrines applicable to corporate entity and limited liability developed with respect to corporations owned by individual investors were thereafter automatically applied to corporate groups. No court apparently recognized that groups involving a number of corporations collectively conducting a common enterprise under common ownership and control presented very different issues than the single corporation with its individual investors. In the case of groups, not only were the public investors of the parent corporation insulated from liability for its obligations, but the parent was insulated from liability for the obligations of its subsidiaries. In the complex multitiered modern multinational, three, four, five or more separate layers of limited liability are not uncommon. This is entity law.

Over the years, in special areas, American law, particularly statutory law, has responded to the inadequacy of entity law. In these special areas, it has recognized enterprise liability principles relying on concepts of "control" and "controlled corporations" to supplement entity law and deal effectively with the problems presented by corporate groups to achieve effective implementation of statutory law or public policy. For most purposes, however, traditional doctrines of corporate juridical entity and limited liability still widely prevail. This traditional conceptual framework creates problems of major proportions for efforts to litigate in the United States actions against American multinationals involving international human rights. ${ }^{7}$

\section{B. Impact of the Conceptual Framework on Conduct of International Human Rights Litigation:}

The atomizing of the single enterprise of the integrated corporate group into hundreds of constituent corporation has serious implications for United States actions alleging violations of international human rights actions in the foreign operations of multinationals.

Under entity law, the law focuses separately on each of the constituent companies - whether American parent or foreign subsidiary - as a separate legal person. For legal purposes in the absence of special statute, it is as if the group did not exist. Parent and subsidiary alike are directly liable only for conduct traceable to their own officers, directors, and employees. While vicarious liability based on equitable "piercing the veil jurisprudence" or agency law or some concept of enterprise law is also available, it has played virtually little or no role in international human rights litigation thus far.

7. For an insightful exploration of this problem in the United Kingdom, see Muchlinski, "Corporations in International Litigation: Problems of Jurisdiction and the United Kingdom Asbestos Cases," 50 Int'l \& Comp. L.Q. 1 (2001). 
Entity law shapes the conduct of the lawsuit. As reviewed in the next section, it creates problems of great magnitude in the area of procedure: the jurisdiction of American courts and the readiness of American courts under the doctrine of forum non conveniens to hear a case when the conduct in question occurred in another country. It may also create problems arising from the interplay of compulsory joinder of parties and diversity jurisdiction.

\section{Procedural Hurdles to Consideration by United States}

Courts of Claims of Human Right Violations by Foreign

Multinational Parent Corporations or Foreign Subsidiaries of American Multinational Groups

\section{A. Jurisdiction}

Human rights abuse overseas, is most likely to involve the foreign affiliates of the group in the area. These are the juridical persons responsible under the concepts of entity law, not the parent company.

However, proceeding against the subsidiary in the United States runs headlong into the barrier of the difficulties of asserting the in personam jurisdiction of an American court over a foreign subsidiary that has no links to the forum except its relationship to its American parent. The subsidiary has typically been incorporated in the foreign jurisdiction. Although part of an American group, it is a national of the host country, not the United States. With a foreign national allegedly committing an offense abroad, what is the basis for American jurisdiction to adjudicate? American ownership and control may suffice under numerous federal statutes for other purposes, but not for purposes of in personam jurisdiction.

Establishing American in personam jurisdiction over a foreign subsidiary of an American multinational is a difficult undertaking. The subsidiary typically has little link to the American jurisdiction. Jurisdiction, if it exists at all, must rest in the relationship of the subsidiary to its parent corporation with jurisdiction resting on the amenability of its domestic parent corporation or sister subsidiary to the local jurisdiction. However, under traditional entity law, each corporation - however, interrelated - is an entirely separate juridical entity, and the mere fact that the parent corporation or a sister group corporation is subject to local jurisdiction is insufficient. Jurisdiction must rest on some theory of vicarious or attributive jurisdiction such as "piercing the veil jurisprudence," agency, or some theory of enterprise jurisprudence. These, too, presents serious problems. Although in scores, if not hundreds of cases, counsel has succeeded in establishing vicarious jurisdiction or substantive tort liability over parent corporations or other controlling individual shareholders, the cases have typically involved idiosyncratic features. The difficulties in the path 
of achieving similar success in the case of the large multinational corporation are profound. ${ }^{8}$

In the sole human rights case that has presented this issue of attributive intragroup jurisdiction, Doe $v$. Unocal Corp., the Court of Appeals for the Ninth Circuit had little difficulty in dismissing an action against the French multinational parent, Total, S.A., whose local subsidiaries and subsidiaries were its sole link to the forum. ${ }^{9}$

Doe $v$. Unocal Corp. ${ }^{10}$ was an action by Burmese plaintiffs against a number of multinational oil companies for alleged participation with the Burmese Government in the exploitation of forced labor in the construction of an oil pipeline. While other defendants were American parent corporations subject to local jurisdiction, Total, S.A., the French parent of the Total Group, moved to dismiss for lack of in personam jurisdiction because it had no contacts with the forum other than its interrelationship with the California subsidiaries of the Total group.

The Court of Appeals for the Ninth Circuit affirmed the lower court's dismissal. Its decision was based on conventional entity law, "the general rule that a subsidiary and the parent are separate entities" and that the mere existence of a relationship between the parent and subsidiary is not sufficient to establish jurisdiction. ${ }^{11}$ The Court followed the conventional doctrine that only where the requirements of traditional "piercing the veil" or "alter ego" jurisprudence ${ }^{12}$ or an agency relationship ${ }^{13}$ may be established, can the barriers of entity law be surmounted; only then, may the local subsidiary's contacts

8. See Phillip I. Blumberg, The Law of Corporate Groups: Procedural Problems in the Law of Parent and Subsidiary Corporations, chs. 3, 4, and 5 (1983 \& Supp. 2001).

9. Doe v. Unocal Corp., 248 F.3d 915 ( $9^{\text {th }}$ Cir. 2001) (action against French multinational corporation Total S.A. dismissed). Readers should note that this manuscript was completed in September 2001.

10. 248 F.3d 915 ( $9^{\text {th }}$ Cir. 2001).

11. 248 F.3d at 926 .

12. The "piercing the veil" and the "alter ego" doctrines although formulated quite differently have identical elements and are "indistinguishable" or "interchangeable," Wm. Passalacqua Bldrs., Inc. v. Resnick Devs. S., Inc., 933 F.2d 131, 138 (2d Cir. 1991) (quoting the author's review of the doctrine in Blumberg, The Law of Corporate Groups: Tort, Contract, and other Common Law Problems in the Substantive Law of Parent and Subsidiary Corporations, ch. 6 (1987 and Supp. 2001).

They both require (1) lack of separate corporate existence arising from lack of the formal requirements or the excessive exercise of control by the parent corporation or controlling shareholder; (2) fraudulent, unjust or inequitable conduct; and (3) causal link to the plaintiffs injury.

13. Common law agency requires a consensual undertaking by the putative principal and agent for the agent to act on behalf of the principal and for its account. Restatement (Third) of Agency $\$ 1.01$ (T.D. No. 2, 2001). This is not common in the ordinary parent/subsidiary relationship where such consent is typically lacking and the subsidiary operates on its own behalf and for its own account although, of course, the parent corporation ultimately benefits. See Kingston Dry Dock Co. v. Lake Champlain Transp. Co., 31 F.2d 265, 267 (2d Cir. 1929). 
with the forum be attributed to the foreign parent for purposes of establishing jurisdiction. ${ }^{14}$

The Court first reviewed its traditional "alter ego" doctrine.

The plaintiff must make out a prima facie case "(1) that there is such unity of interest and ownership that the separate personalities [of the two entities] no longer exist and (2) that failure to disregard [their separate entities] would result in fraud or injustice. ${ }^{15}$

The scope of the doctrine rests not on the metaphorical statement of the standard, but in the judicial gloss over the years.

Application of the standard is extremely fact-intensive and this renders generalization difficult. If carried to an extreme, the parent's control may eliminate the separate existence of the subsidiary, but what degree of control exercised by the parent over its subsidiaries may be deemed excessive? As the Supreme Court recently recognized in United States v. Bestfoods, it is appropriate for the parent to be involved in "monitoring of the subsidiary's performance, supervision of the subsidiary's finance and capital budget decisions and articulation of general policies and procedures." 16 But how much further may it go? At the far end of the continuum, virtually all American jurisdictions agree that the parent's control of the subsidiary's day-today operations is unacceptable and will support application of "piercing" doctrines. Other factors leading to the same result cited by the Court included use of the subsidiary as a marketing conduit and to shield from liability or inadequate capitalization. ${ }^{17}$

In Doe v Unocal Corp., the plaintiffs had offered no evidence of day-to-day control. Instead, they relied on an extensive series of factors illustrating the close interrelationship between the companies of the group. They pointed to the French parent's involvement in its subsidiaries' acquisitions, divestments and capital expenditures; in the formulation of general business policies, strategies, and targets for investment; in financing support including loans (but this was dismissed because they were all interest bearing and documented); overlapping directors and officers; and references to the subsidiaries as "divisions." While plaintiffs contended in addition that the subsidiaries were undercapitalized to implement their active acquisition pol-

14. 248 F.3d at $925-926$.

15. 248 F.3d at 926 .

16. 524 U.S. 51, 69 (1998).

17. The extent of the role of "inadequate capitalization" in "piercing" jurisprudence is much debated. It ranges from jurisdictions such as California and the Ninth Circuit in which inadequate capitalization without more may establish lack of separate corporate existence to jurisdictions such as the Seventh Circuit in which its significance is dismissed except in a very narrow band of circumstances. Compare Slottow v. American Cas. Co. of Reading, Pa., 10 F.3d 915, 926 ( $9^{\text {th }}$ cir. 2001) with Browning-Ferris Indus. of Ill., Inc v. Ter Maat, 195 F.3d 853 ( $7^{\text {th }}$ Cir. 199) (Posner, C.J.). 
icy, the Court held this was irrelevant since they were adequately capitalized to protect their existing holdings. ${ }^{18}$

In conclusion, the Court found that the while the parent was an "active parent corporation involved directly in decision-making about its subsidiaries' holdings," this was insufficient. It concluded that because the group companies had observed "all of the formalities necessary to maintain corporate separateness," the separateness factor in the alter ego test had not been satisfied. ${ }^{19}$ The Court, therefore, found it unnecessary to determine whether the corporate structure was being manipulated to bring about an unjust or inequitable result.

The Court similarly held that the so-called "agency" standard for jurisdiction for attribution of contacts or local activities of the domestic group company had not been satisfied. This is not common-law agency, but a sui generis doctrine, not invoked in most American jurisdictions, but accepted by several major jurisdictions, including the Ninth Circuit and New York. As stated by the Court, "courts have permitted the imputation of contacts where the subsidiary was "either established for, or is engaged in, activities that, but for the existence of the subsidiary, the parent would have to undertake itself." 20

Although Doe v. Unocal Corp. is the only decision considering the problems of attribution of jurisdiction in international human rights cases involving multinational corporations, the Court's treatment of the problem and the outcome of the case is entirely consistent with American law in this general area. It illustrates vividly the effectiveness of entity law in shielding the overseas affiliates of multinational groups from American jurisdiction.

The international human rights cases relate to alleged abuses occurring abroad and accordingly most likely to involve the foreign affiliates of the group in the area. The great difficulties of asserting American jurisdiction over such overseas companies creates pressure on plaintiff's counsel to proceed instead against the American parent corporation or other American affiliates. In the overwhelming majority of cases, counsel, perhaps for this reason, ${ }^{21}$ has thus proceeded not against a foreign subsidiary, but against the American parent

18. 248 F.3d at $926-27$.

19. 248 F.3d at 927.

20. 248 F.3d at 928, citing the approval by Chan v. Society Expeditions, Inc., 39 F.3d 1398, 1405 ( $9^{\text {th }}$ Cir. 1994) quoting Gallagher v. Mazda Motor of Am., Inc., 781 F. Supp. 1079, 1083-84 (E.D. Pa. 1992). See also Frummer v. Hilton Hotels Int'l., Inc., 19 N.Y. 2d 533, 537, 227 N.E. 2d 851 (1967); Gelfand v. Tanner Motor Tours, Ltd., 385 F.2d 116, 120-21 (2d Cir. 1967); Blumberg, The Law of Corporate Groups: Procedural Problems in the Law of Parent and Subsidiary Corporations, $\$ 4.02 .1$ (1983 \& Supp. 2001).

21. Another possible explanation is counsel's concern with the problem of forum non conveniens. Such problems, difficult to begin with because the cases typically involve plaintiffs who are foreign residents would be intensified with a foreign defendant as well. 
corporation instead. This disposes of any jurisdictional issue. The American parent corporation is, of course, readily amenable to assertion of in personam jurisdiction in any state in which it is incorporated or is doing business. ${ }^{22}$ It also maximizes the possibilities of collectability of the judgment in the event the suit is successful.

While instituting an action against the parent corporation solves the jurisdictional and collectability problems, it does so at the high cost of creating problems of its own. First, it creates serious difficulties in the preparation of the complaint. Unless the case rests on the vicarious liability of the parent corporation under traditional "piercing the veil jurisprudence," agency law, or some theory of enterprise liability, the plaintiff must allege and prove the parent's participation in the acts complained. In most cases, this presents very difficult problems for counsel. On pleading, Federal Rule 12(b)(6) requires specific allegations of the involvement of the parent corporation in the tortious actions complained of. ${ }^{23}$ General conclusory allegations of the parent's participation and control are insufficient. In consequence, before reaching the next barrier of whether the court will exercise its jurisdiction in the light of the doctrine of forum non conveniens, some human rights complaints have been dismissed under Federal Rule 12(b)(6) for failure to state a cause of action. ${ }^{24}$ This is the direct product of the practical consequences of the application of entity law concepts in determining the amenability of foreign subsidiaries of American corporate groups to suits in the United States. Even if the complaint survives the pleading challenge, the difficulties of establishing the parent's direct involvement in the conduct complained of remains. Where the subsidiary has been the actor or principal actor, this has proved well nigh impossible ${ }^{25}$ except in a few defective pharmaceutical drug cases involving the design and testing, and in some case, the manufacture of the drug in the United States. ${ }^{26}$ In no American case that has gone to decision on the merits has counsel been able to do this. By contrast, English counsel has

22. This, of course, is so even if the American multinational has its principal place of business abroad. Cf. Torres v. Southern Peru Copper Co., 113 F.3d 540 ( $5^{\text {th }}$ Cir. 1997). In some cases, counsel has proceeded against the foreign subsidiary as well as against the parent, but the controversies, thus far, have mostly been determined without consideration of the issues involving the subsidiary.

23. F. Rule of Civ. P. 12 (b)(6).

24. Beanal v. Freeport-McMoran, Inc., 197 F.3d 161 ( $5^{\text {th }}$ Cir. 1999); Iwanowa v. Ford Motor Co., 67 F. Supp. 2d 424 (D.N.J. 1999). But see Doe v. Unocal Corp., 963 F. Supp. 880 (C.D. Cal. 1997) (complaint held sufficient under Rule 12(b)(6)).

25. These problems have been rendered even more difficult by the decision of the Supreme Court in United States v. Bestfoods, 524 U.S. 51 (1998). In Bestfoods, arising under the environmental law punishing "operator[s]" of facilities with hazardous wastes, the Court held that the parent corporation was not liable for hazardous wastes at a plant of its wholly owned subsidiary even though the persons acting as directors and officers of the subsidiary and participating in the prohibited conduct were also directors and officers of the parent.

26. See infra n. 35 . 
had greater success in establishing direct participation in the form of acts taken in England by officials of the English parent corporations charged with international human rights violations. ${ }^{27}$

While actions asserting personal liability against American nationals directly involved in the conduct as directors, officers, or employees of the foreign subsidiary do not involve such technical difficulties, no case has apparently pursued this alternative approach notwithstanding its attractive prospects. ${ }^{28}$

\section{B. Forum Non Conveniens}

The mere fact that its case satisfies the requirement for subject matter jurisdiction and in personam jurisdiction over the defendant and the normal requirements of the forum with respect to venue does not without more enable the plaintiff to proceed. The defendant may still contend that the court should defer the exercise of its jurisdiction because another forum is more appropriate. This is the doctrine of forum non conveniens ("FNC"). ${ }^{29}$

In the past, this issue presented only issues of minor professional interest. With the emergence of the global economy and of the predominance of multinational enterprises conducting worldwide business, however, the scene has dramatically changed.

Unlike the civil law countries, the United States and other common law jurisdictions apply the doctrine of forum non conveniens. This is part of the federal procedural law and has been accepted by almost all the states. ${ }^{30}$ Under the doctrine, an American court with in personam jurisdiction and subject matter jurisdiction may, nevertheless, in its discretion, decline to hear the case where another forum is available and more appropriate. The doctrine permits the court to do so where it finds that the plaintiff's choice of the forum would be inappropriate because of the burdens imposed on the defendant are "out of all proportion to the plaintiff's convenience" or because of "considerations affecting the court's own administrative ... and legal problems." ${ }^{31}$ The trial court has discretion to determine

27. Cf. Connelly v. RTZ Corp., plc, 3 W.L.R. 375 (H.L. 1997); Lubbe v. Cape plc, 1 W.L.R.1545 (H.L. 2000).

28. Corporate officers, directors, and employees are responsible for their participation in tortious conduct even though they do so in the name of the corporation for the benefit of the corporation. E.g. Delong Equip. Co. v. Washington Mills Abrasive Co., 840 F.2d 843 (11 ${ }^{\text {th }}$ Cir. 1998) cert. denied, 494 U.S. 1081 (1990); Union Mut. Life Ins. Co. v. Chrysler Corp., 793 F.2d 1, $11\left(1^{\text {st }}\right.$ Cir. 1986); Adams v. NVR Homes, Inc., 135 F. Supp. 2 d 675 (D. Md. 2001); Special Purpose Accounts Receivable Co-op. Corp. v. Prime One Capital Co., L.L.C., 125 F. Supp. 2d 1093 (S.D. Fla. 2000). See generally $3 \mathrm{~A} \mathrm{~W}$. Fletcher, Cyclopedia of the Law of Private Corporations $\$ 1135$ (repl. vol. 2000). 29. See generally also 15 C. Wright, A. Miller \& E. Cooper, Federal Practice \& Procedure $\$ 3828$ (1986).

30. E.g., Gulf Oil Corp. v. Gilbert, 330 U.S. 501 (1947); Piper Aircraft Co. v. Reyno, 454 U.S. 235 (1981).

31. See Koster v. Lumbermens Mut. Cas. Co., 330 U.S. 518, 524 (1947). 
"where trial will best serve the convenience of the parties and the ends of justice." 32 A domestic plaintiff's choice of forum is widely respected under the doctrine. The doctrine is particularly applicable to foreign plaintiffs as occurs in the overwhelming bulk of international human rights litigation.

In recent years starting with the celebrated Bhopal case, ${ }^{33}$ there have been numerous international human rights cases ${ }^{34}$ in American courts against American multinational parent corporations, contending that their actions resulted in injuries to foreign workers, consumers, or residents. International human rights litigation has become an important weapon in the arsenal of public interest groups. Foreign plaintiffs have attempted to litigate actions in the United States against domestic parent corporations and sometimes their foreign subsidiaries as well for alleged wrongful actions injuring persons abroad. Increasing numbers of cases have been brought in tort for defective products involving injuries to large numbers of persons from dangerous pharmaceutical drugs, pesticides, and herbicides, and to workers for injuries resulting from dangerous working conditions. More recently, such litigation has broadened to include class actions alleging environmental abuses abroad injuring large numbers of indigenous peoples in the area. ${ }^{35}$ While many have been common

32. Id. at 527 .

33. In re Union Carbide Corp. Gas Plant Disaster of Bhopal, 809 F.2d 195 (2d Cir.), cert. denied sub nom. Executive Committee Members v. Union of India, 484 U.S. 871 (1989).

34. Similarly one may distinguish in actions involving defective agricultural fungicides between actions for economic loss by commercial nurseries or commercial fish farms on the one hand and actions by extensive numbers of Latin American agricultural workers for personal injuries on the other, with only the latter viewed as presenting issues of international human rights.

Nevertheless, the jurisprudence in all these cases insofar as the applicability of $F N C$ is concerned is identical, except for the recent recognition by the Court of Appeals for the Second Circuit that in the case of international human rights violations falling within the Alien Tort Claims Act (ATCA) and the Torture Victim Protection Act, the congressional interest in assuring the availability of a United States remedy must be taken into account in evaluating the public interest factors governing the applicability of $F N C$.

35. Forced Labor and Torture: Wiwa v. Royal Dutch Petroleum Co., 226 F.3d 88 (2d Cir. 2000) (Leval, J.) (Nigeria) (ATCA), cert. denied, S.Ct. (2001); Iwanowa v. Ford Motor Co., 67 F. Supp. 2d 424 (D.N.J. 1999) (WW II Germany) (ATCA); Doe v. Unocal Corp., 248 F.3d 915 ( $9^{\text {th }}$ Cir. 2001) (jurisdiction over Total S.A.); and 963 F. Supp. 880 (C.D. Cal. 1997) (pleading against Unocal Corp.) (Burma gas pipeline).

Massive environmental damage: Jota v Texaco, Inc. 157 F.3d 153 (2d Cir. 1998) (Newman, J.), rev'g Aguinda v. Texaco, Inc., 945 F. Supp. 625 (S.D.N.Y.1999) (Amazon rain forests) (ATCA) on remand, 139 F. Supp. 2d 139 F. Supp. 2d 438 (S.D.N.Y. 2000), 142 F. Supp. 2d 533 (S.D.N.Y. 2001) (dismissing complaint); Beanal v. Freeport-McMoran, Inc., 197 F.3d 161 ( $5^{\text {th }}$ Cir. 1999) (Indonesian rivers and rain forest) (ATCA); Sequihua v. Texaco, Inc., 847 F. Supp. 61 (S.D. Tex. 1994 (Ecuador).

Toxic Emissions: Dow Chemical Co. v. Republic of India, 809 F.2d 197 (2d Cir. 1987); Torres v. Southern Peru Copper Corp., 113 F.3d 540 (5 $5^{\text {th }}$ Cir. 1997).

Defective drugs, pesticides, and fungicides: Federal consumer decisions include: Cabalceta v. Standard Fruit Co., 883 F.2d 1553 (11 ${ }^{\text {th }}$ Cir. 1989); Sibaja v. Dow Chem. 
law actions, they have also involved suits under the Federal Alien Torts Act and the Torture Victim Protection Act alleging forced labor and environmental abuse. In each, forum non conveniens has played a central role in the litigation. While, as will be seen, the courts have overwhelmingly applied the doctrine to bar litigation in the United States, there are some signs of change, particularly in litigation involving the Federal Alien Tort Claims Act (ATCA) and Torture Victims Protection Act (TVPA).

These cases have attracted considerable public attention. Public interest groups have contended that they present vital public questions as to the responsibility of American multinational corporations in the conduct of their business abroad and that the American courts have a special responsibility to permit such matters to be litigated in the United States. Forum non conveniens is no longer a minor procedural doctrine. It is producing intense public controversy, involves an increasing body of litigation, and has led to the emergence of a substantial legal literature. ${ }^{36}$

Co., 757 F.2d 1215 (11 ${ }^{\text {th }}$ Cir. 1985); Delgado v. Shell Oil Co., 231 F.2d 165 (5 $^{\text {th }}$ Cir. 2000) (agricultural workers); Watson v. Merrell-Dow Pharmaceuticals, Inc., 769 F.2d 354 (6 $^{\text {th }}$ Cir. 1985); Dowling v. Richardson-Merrell, Inc., 727 F.2d 608 (6 ${ }^{\text {th }}$ Cir. 1984); Harrison v. Wyeth Labs. Div'n, 510 F. Supp. 1 (E.D. Pa. 1980), affd mem. 676 F.2d 685 (3d Cir. 1982); In re Silicon Gel Breast Implant Litig., 887 F. Supp. 1469 (N.D. Ala. 1995) (silicon gel). State consumer decisions include: Ison v. E.I. DuPont de Nemours \& Co., 729 A.2d 832 (Del. 1999) (Veasey, C.J.); Picketts v. International Playtex, Inc., 215 Conn. 490, 576 A.2d 518 (1990) (consumers) (applying state not federal standards) (Peters, C. J.); Dow Chem. Co. v. Alfaro, 786 S.W.2d 674 (1990) ( $F N C$ then not recognized in Texas) (rejecting application of $F N C$ ); and Chambers v. Merrell-Dow Pharmaceuticals, Inc., 35 Ohio St. 3d 123, 519 N.E. 2d 370 (1988) (applying common-law standards and citing Gulf Oil and Piper) (applying FNC).

Commercial cases include: Proyectos Orchimex de Costa Rica, S.A. v. E.I. du Pont de Neours \& Co., 896 F. Supp. 1197 (M.D. Fla. 1995) Ciba-Geigy Ltd., The Fish Peddler, Inc., 691 So. 2d 1111 (Fla. Dist. Ct. App. 1996) (commercial growers).

Litigation against multinational corporations for defective drugs forms a jurisprudence of its own. The problem is affected by the critical fact that the drugs in issue have often originally been developed in the United States even if later produced and marketed abroad. Although most courts have rejected American litigation in reliance on forum non conveniens, some federal courts and at least two major decisions in state courts have upheld suit in the United States. These courts have been influenced by the presence of witnesses and files in the United States relating to the research and development. Carlenstope v. Merck \& Co., 819 F.2d 33 (3d Cir. 1987); Chan Tse Ming v. Cordis Corp., 704 F. Supp. 217 (S.D. Fla. 1989); Ison v. E.I. DuPont de Nemours \& Co., 729 A.2d 832 (Del. 1999) (Veasly, C.J.) (applying Delaware "overwhelming hardship" standard); Picketts v. International Playtex, Inc., 215 Conn. 490, 576 A.2d 518 (1990) (Peters, C.J.).

36. For the more recent literature, see, e.g., Cassels, "Outlaws: Multinational Corporations and Catastrophic Laws," 33 Cumb. L. Rev. 311 (2000/2001); Dunham \& Gladbach, "Forum non conveniens and foreign plaintiffs in the 1990s," 24 Brook. J. Int'l L. 665 (1999); Kalas, "The Implications of Jota v. Texaco and the Accountability of Transnational Corporations," 12 Pace Int'l L. Rev. 47 (2000); Reed, "To Be or Not to Be: The Forum Non Conveniens Performance Acted Out on Anglo-american Courtroom Stages," 29 Ga. J. Int'l \& Comp. L. 31 (2000); Rogge, "Towards Transnational Corporate Accountability in the Global Economy: Challenging the Doctrine of Forum non Conveniens in In re: Union Carbide, Alfaro, Sequihua, and Aguinda," 36 Tex. Int'l L. J. 299 (2001); Comment, "Forum Non Conveniens Dismissals and the Adequate 
The ensuing debate has become politicized. Civic groups concerned with "policing" the foreign activities of American-based multinationals in such areas as mass catastrophes or dangerously defective drugs, fungicides, and herbicides, the environment, child labor, and dangerous working conditions have condemned utilization of the doctrine to prevent trial of the matter in American forum. They do not rest their case for an American hearing and determination of these alleged abuses on the traditional factors for permitting a local determination of a foreign controversy. Instead, they attack the adequacy of the judicial system governing the alternative foreign forum. They point to the unavailability of such features of the American judicial system as legal aid, contingent fee arrangements, punitive damages, liberal discovery, and trial by jury, the existence of low limits on tort awards, unfamiliarity with product liability matters, and long delays before trial. They express indignation as to the impropriety of using procedural "technicalities" to bar an American hearing of the alleged misconduct of American multinationals.

To date, these arguments, however, have not prevailed. ${ }^{37}$ Using traditional standards for applying the doctrine, American courts have almost always referred these foreign plaintiffs to the foreign jurisdictions in which the alleged injuries were incurred and whose law gov-

Alternative Forum Question: Latin American," 32 U. Miami Inter-am. L. Rev. 295 (2001); Note, "ATCA's Achilles Heel: Corporation Complicity, Internation Law and the Alien Tort Claims Act," 26 Yale J. Int'l L. 487 (2001); Note, "Enforcement of Human Rights on Multi-National Corporations: Global Climate, Strategies and Trends for Compliance," 28 Denv. J. Int'l L. \& Pol'y 339 (2000); Comment, "The United States as a forum for human rights litigation: Is this the best solution?," 14 Transnat'l Law. 207 (2001); Note, "Enforcement of Corporate Codes of Conduct: Finding a Private Right of Action for International Laborers against MNCs for Labor Rights Violation," 19 Wis. Int'l L. J. 41 (2000). See also Meeran, "The Unveiling of Transnational Corporations," in Human Rights Standards and the Responsibility of Transnational Corporations 161-70 (Michael Addo, ed. 1999).

For earlier literature, see Birnbaum \& Dunham, "Foreign Plaintiffs and Forum Non Conveniens," 16 Brook. L. Rev. 241 (1991); Speer, "The Continued Use of Forum Non Conveniens: Is it Justified?," 58 J. Air L. \& Com. 845 (1993); Duval-Major, "OneWay Ticket Home: The Federal Doctrine of Forum Non Conveniens and the International Plaintiff," 77 Corn. L. Rev. 650 (1992); Solen, "Forum Non Conveniens and the International Plaintiff," 9 Fla. J. Int'l L. 343 (1992) (hereinafter cited as Solen); White, "Home Field Advantage: The Exploitation of Federal Forum Non Conveniens by United States Corporations and its Effects on International Environmental Litigation, "26 Loy. L.A. L. .Rev. 491 (1993); Miller, "Forum Non Conveniens and State Control of Foreign Plaintiff Access to U.S. Courts in International Tort Actions," $58 \mathrm{U}$. Chi. L.Rev. 1369 (1991); Woods, "Suits by Foreign Plaintiffs: Keeping the Doors of American Courts Open," 8 Ariz. J. Int'l \& Comp. L. 75 (1991).

37. For a passionate and eloquent expression of this view not accepted by any other court or judge, see Dow Chem. Co. v. Alfaro, 786 S.W.2d 674 (Tex. Ct. App. 1990)(Doggett, J. concurring)(Costa Rica law lacked jury trial, deposition of non-party witnesses and contained a maximum limit on recovery of about $\$ 1,080$ per plaintiff in case for alleged sterility and other injuries allegedly resulting from use of chemical pesticides) ("what is really involved is not inconvenience but connivance to avoid corporate accountability"). For an endorsement of this view, see J. Bonsignore, Law and Multinationals: An Introduction to Law and Political Economy ch. 10 (1994). 
erns the case. Although the Supreme Court has observed that the discretionary nature of the doctrine and the many factors controlling its application make uniformity of decision and predictability almost impossible, ${ }^{38}$ this does not apply in the area of international human rights. FNC has proved to be an insuperable obstacle to American trial in virtually every case.

\section{General Doctrine in the United States}

In two major decisions, Gulf Oil Corp. v. Gilbert ${ }^{39}$ involving American torts and Piper Aircraft Co. v. Reyno, ${ }^{40}$ involving a Scottish aircraft crash, the Supreme Court outlined the general standards for application of forum non conveniens in the federal courts. ${ }^{41}$ These standards govern FNC law today.

For general purposes the courts agree that application of the doctrine involves consideration of a complex series of factors:

a. The threshold issue is whether there is an adequate alternative forum capable of providing effective relief for the plaintiff. The doctrine may not be used to deprive the plaintiff of its right to try its case in some forum. Thus, where the foreign forum recognizes no cause of action for the plaintiff ${ }^{42}$ or because of the systemic inadequa-

38. American Dredging Co. v. Miller, 510 U.S. 443 (1994).

39. Gulf Oil Corp. v. Gilbert, 330 U.S. 501 (1947).

40. Piper Aircraft Corp. v. Reyno, 454 U.S. 235, 250-61 (1981).

41. In the American federal system for purposes of federal or state choice of law in diversity matters in the federal courts under the rule of Erie R.R. v. Tompkins, 304 U.S. 64 (1938). FNC is widely regarded as a doctrine of procedure to be applied even in federal diversity matters. In Gulf Oil Corp. v. Gilbert, the Supreme Court refrained from ruling on whether $F N C$ was to be treated as procedural or as substantive. Gulf Oil Corp. v. Gilbert, 330 U.S. 501, 509 (1947). See also Koster v. American Lumbermen's Mut. Cas. Co, 330 U.S. 518, 529 (1947). The lower federal courts, however, have overwhelmingly treated it as procedural. E.g., Rivendell Forest Prods. v. Canadian Pac. Ry., 2 F.3d 990 (10th Cir. 1993); In re Aircraft Crash near New Orleans, 821 F.2d 1147, 1154-59 (5th Cir. 1987).

Finally, in 1994, the Supreme Court held that the issue was procedural for state court purposes enabling state courts to apply state FNC law in admiralty matters. American Dredging Co. v. Miller, 114 S. Ct. 981 (1994). If FNC is procedural in admiralty matters in the state courts, this strongly reinforces the conclusion that FNC should also be treated as procedural in federal diversity matters.

See generally 15 C. Wright, A. Miller, \& E. Cooper, Federal Practice and Procedure $\$ 3828$ (1986). These commentators agree that $F N C$ should be treated as procedural for federal diversity purposes. However, at least prior to American Dredging, not all commentators agreed. See Stein, "Erie and Court Access," 100 Yale L.J. 1935 (1991) (hereinafter cited as Stein).

While federal concepts of $F N C$ do not bind the states, most states have chosen to be guided by them. Thus, federal concepts of $F N C$ govern in the states as a practical matter. However, in a number of states, particularly Delaware and perhaps Connecticut, state courts have fashioned their own, less restrictive rules

42. Thus in certain wrongful death actions, even where FNC has been applied to dismiss an action with respect to adult plaintiffs, it has been denied in the case of minors or children en ventre sa mere for whom the foreign jurisdiction did not recognize the capacity to institute such actions. E.g., Calavo Growers of Cal. v. Belgium, 632 F.2d 963 (2d Cir. 1980) (Newman, J.); Fiorenzo v. United States Steel Int'l, 311 F. 
cies of the foreign jurisdiction, the plaintiff as a practical matter would not be able to litigate, $F N C$ is not to be applied.

b. In Piper, the Supreme Court made it plain that while domestic plaintiffs should be afforded "substantial deference" in their choice of forum, courts should be "less solicitous" in the case of foreign plaintiffs "seek[ing] to benefit from the more liberal tort rules provided for the protection" of Americans. ${ }^{43}$ Further, there is a manifest hostility to what is perceived as "forum shopping" by foreign plaintiffs seeking not only the more liberal tort doctrines but the more liberal practice rules of the United States. ${ }^{44}$ The defendant seeking to invoke the doctrine has the burden of proof with respect to all elements of the doctrine and is said to have a "heavy burden," 45 but the fact of the matter is that the doctrine is frequently applied.

c. Gilbert and Piper outlined certain so-called "private interest" factors and "public interest" factors that courts were to take into account in their analysis. The "private interest" factors include:

(The) relative ease of access to sources of proof; availability of compulsory process for attendance of unwilling, and the cost of obtaining attendance of willing, witnesses; possibility of view of the premises, if . . appropriate . . ; and all other practical problems that make trial of a case easy, expeditious and inexpensive. There may also be question as to the enforceability of a judgment. . . . ${ }^{46}$ follows:

d. Piper and Gilbert established "public interest" factors as

Administrative difficulties for courts when litigation is piled up in congested centers instead of being handled at its origin. Jury duty is a burden that ought not to be imposed upon the people of a community with no relation to the litigation. In cases which touch the affairs of many persons, there is reason for holding the trial in their view and reach ... There is a local interest in having localized controversies decided at home. There is an appropriateness, too, in having the trial of a diversity case in a forum that is at home with the state law that must govern the case, rather than having a court is

Supp. 117 (S.D.N.Y. 1968); Chambers v. Merrell-Dow Pharmaceuticals, Inc., 35 Ohio St. 2d 123, 519 N.E.2d 370 (1988).

43. See Piper Aircraft Co. v. Reyno, 454 U.S. 235, (1981). For different treatment of domestic and foreign plaintiffs in the same case, see Macedo v. Boeing Co., 693 F.2d 983 (7th Cir. 1982).

44. See Silberman, "Developments in Jurisdiction and Forum non Conveniens in International Litigation: Thoughts on Reform and a Proposal for a Uniform Standard," 28 Tex. Int'l L. J. 501, 525-26 (1993).

45. See Hodson v. A.H. Robins Co., 528 F. Supp. 809 (E.D. Va. 1981), aff'd, 715 F.2d 142 (4th Cir. 1983).

46. Gulf Oil Corp. v. Gilbert, 330 U.S. 502, 506-07 (1947); Piper Aircraft Co. v. Reyno, 454 U.S. 235, 250-61 (1981). 
some other forum untangle problems in conflict of laws, and in a law foreign to itself. ${ }^{47}$

e. Application of the doctrine is stated to be within the discretion of the trial court. The rule only establishes the outer limits for the trial judge's exercise of discretion. Only "clear abuse" may be reversed. ${ }^{48}$

In one vital area, the courts appear not to be in agreement. There is some disagreement over the role of the public interest factors. Thus, two decades ago, the Court of Appeals for the District of Columbia in a foreign aircraft crash disaster case appeared to suggest that the public interest factors were secondary, to be considered only when the private interest factors were "in equipoise or near equipoise." 49 In much the same vein, the Court of Appeals for the Fifth Circuit has concluded that where the court has determined the availability of an adequate alternative forum and that the private interest factors strongly favor dismissal, there is no need to consider the public interest factors. ${ }^{50}$ While some decisions centered in Florida have recognized the "equipoise" doctrine, ${ }^{51}$ this is far from the federal practice. The courts regularly examine the public interest as well as the private interest factors.

Such is the prevailing practice in the United States in the application of FNC. The doctrine evolved in private controversies in which the special values and significance of the later international human rights litigation played no role. Nevertheless, as will be seen, the general doctrine has been firmly applied to international human rights issue without any modification. We now turn to an examination of this recent wave of litigation.

\section{FNC and International Human Rights Litigation}

Following the lead of Gilbert and Piper, American courts have widely rejected the significance of the existence of the systemic deficiencies in the foreign legal system as factors determining whether an alternative forum is realistically available. Even in the cases in-

47. Id. at 508-09.

48. Piper Aircraft Co. v. Reyno, 454 U.S. 235, 257, 263 (1945); Gulf Oil Corp. v. Gilbert, 330 U.S. 501, 511-12 (1947). Notwithstanding the generous scope accorded the trial court's discretion by the appellate opinions, numerous appellate courts have not refrained from reversing lower court decisions in this area, often remanding with directions to consider the factual implications of some neglected aspect of the case. See, e.g., Macedo v. Boeing Co., 693 F.2d 683 (7th Cir. 1982); Picketts v. International Playtex, Inc., 576 A.2d 518 (Conn. 1990).

49. See Pain v. United Tech. Corp., 637 F.2d 775 (D.C. Cir. 1980).

50. See Empresa Lineas Maritimas v. Schichau-Onterweiser, AG, 955 F.2d 368, 376 ( $^{\text {th }}$ Cir. 1992); Delgado v. Shell Oil Co., 890 F. Supp. 1324, 1370 (S.D. Tex. 1995), affd 231 F.3d 165 ( $5^{\text {th }}$ Cir. 2001).

51. See, e.g., Ciba-Geigy Ltd. v. The Fish Peddler, Inc., 691 So. 2d 1111 (Fla. Dist. Ct. App. 1996); Kinney Sys., Inc. v. Continental Ins. Co., 674 So. 2d 86 (Fla. 1996). 
volving international human rights where the deficiencies are particularly harmful, no court has concluded that they have deprived plaintiff of an adequate alternative forum or resulted in a denial of justice. ${ }^{52}$ The systemic deficiencies of foreign legal systems that have been deemed insufficient include such serious limitations of the foreign legal system as:

1. The unavailability of legal aid or of contingent fee representation. ${ }^{53}$

2. The requirement that a plaintiff must pay the fees and costs of the defendant in the event it does not prevail. ${ }^{54}$

3 . The absence of trial by jury. ${ }^{55}$

4. The unavailability of deposition in lieu of live witnesses. ${ }^{56}$

5. The likelihood of smaller damage awards. ${ }^{57}$

6. The unavailability of punitive damages. ${ }^{58}$

7. Absence of relief for non-economic harm. ${ }^{59}$

8. The unavailability of class action proceedings. ${ }^{60}$

52. This may be compared with Connelly v. RTZ Corp., plc., 3 W.L.R. 373 (H.L. 1997) where the House of Lords rejected the application of the English doctrine of $F N C$ in part. Although the Lords recognized that the foreign jurisdiction was the appropriate forum, they refused to apply $F N C$ because it would lead to a denial of justice. Among other things the Court was concerned with the heavy expense in volved in obtaining necessary scientific testimony for which the necessary funds to pursue the litigation would not be available if the case were tried in Namibia rather than England.

53. E.g., Magnin v. Teledyne Continental Motors, 91 F.3d 1424 (11th Cir. 1996); Dowling v. Richardson-Merrell, Inc., 727 F.2d 608 (6th Cir. 1984); Macedo v. Boeing Co., 693 F.2d 683 (7th Cir. 1982) (Portuguese plaintiffs); Delgado v. Shell Oil Co., 890 F. Supp. 1324 (S.D. Tex. 1995), affd 231 F.3d 165 ( $5^{\text {th }}$ Cir. 2001); Hodson v. A.H. Robins Co., 528 F. Supp. 809 (E.D. Va. 1981), affd, 714 F.2d 142 (4th Cir. 1983), (relying on Fiorenza v. United States Steel Int'l, 311 F. Supp. 117 (S.D.N.Y. 1968) (pre-Piper); Coates v. Arabian American Oil Co., 831 F.2d 572 (5 ${ }^{\text {th }}$ Cir. 1985).

54. Dowling v. Richardson-Merrell, Inc., 727 F.2d 608 (6th Cir. 1984); Macedo v. Boeing Co., 693 F.2d 683 (7th Cir. 1982) (Portuguese plaintiffs); Torres v. Southern Peru Copper Co., 113 F.3d 540 (5th Cir. 1997).

55. Dowling v. Richardson-Merrell, Inc., 727 F.2d 608 (6th Cir. 1984); Macedo v. Boeing Co., 693 F.2d 683 (7th Cir. 1982) (Portuguese plaintiffs); Magnin v. Teledyne Continental Motors, 91 F.3d 1424 (11th Cir. 1996); Delgado v. Shell Oil Co., 890 F. Supp. 1324 (S.D. Tex. 1995).

56. Delgado v. Shell Oil Co., 890 F.Supp 1324 (S.D. Tex. 1995), affd, 231 F.3d 165 (5 $5^{\text {th }}$ Cir. 2000).

57. Delgado v. Shell Oil Co., 890 F.Supp 1324 (S.D. Tex. 1995), affd, 231 F.3d 165 ( $5^{\text {th }}$ Cir. 2000). But see Irish National Ins. Co. v. Aer Lingus Teoranta, 739 F.2d 90, 91 (2d Cir. 1984) (FNC unavailable if foreign jurisdiction imposes "such severe monetary limitations as to eliminate the likelihood that the case will be tried").

58. E.g., Macedo v. Boeing Co., 693 F.2d 683 (7th Cir. 1982) (Portuguese plaintiffs).

59. Delgado v. Shell Oil Co., 890 F.Supp 1324 (S.D. Tex. 1995), aff'd 231 F.3d 165 $\left(5^{\text {th }}\right.$ Cir. 2000).

60. Aguinda v. Texaco, Inc., 945 F. Supp. 626 (S.D.N.Y.) 1996), rev'd on other grounds sub nom. Jota v. Texaco, Inc., 157 F.3d 153 (5 $5^{\text {th }}$ Cir. 1998), reinstated on remand sub nom. Aguinda v. Texaco, Inc., 142 F. Supp. 2d 532 (S.D.N.Y) 2001). 
9. The unavailability of joinder. ${ }^{61}$

10. The absence of experience with product liability litigation. ${ }^{62}$

11. Overcrowded dockets and trial delays. ${ }^{63}$

12. Less advantageous foreign substantive law. ${ }^{64}$

Nevertheless, the courts have accepted such deficiencies and have applied the doctrine. The explanation is evident. International human rights cases are tort cases arising in a foreign jurisdiction, and the private interest factors exert a near irresistible pressure for foreign trial where the events took place. Even where the courts view such limitations with concern, as reviewed below, they continue to apply $F N C$ on the condition that the defendant consent or stipulate to correct the problem.

When courts have applied $F N C$ notwithstanding these deficiencies and have required the plaintiff to proceed in the foreign forum, they have assumed that the forum is available and that the plaintiff, accordingly, is not being deprived of its day in court. In no case, however, does there appear to have been any empirical demonstration of the reality or lack of reality of this theoretical assumption. A ten-year old study of $F N C$ cases by one commentator strongly suggests that in most of the cases, an American decision to apply the doctrine has effectively meant the end of the case. ${ }^{65}$ It remains to be seen the extent to which American courts will continue to be ready to apply FNC where counsel introduces credible evidence in the record establishing this bleak reality.

The widespread concern in the United States with respect to the overloaded judicial system with heavy judicial dockets already straining the legal system strongly reinforces the already formidable impact of the private interest factors. Thus, in Proyectos $v$. Orchinex de Costa Rica, S.A. v. E.I. DuPont de Nemours \& Co., the court described in graphic terms the impact on the district of accepting one international product liability litigation:

these are complex and highly contested cases often featuring lengthy trials ... The trial of these seven cases alone could occupy one of the three federal judges [in the district] full

61. Delgado v. Shell Oil Co., 890 F.Supp 1324 (S.D. Tex. 1995), affd 231 F.3d 165 ( $5^{\text {th }}$ Cir. 2000).

62. Macedo v. Boeing Co., 693 F.2d 683 (7th Cir. 1982) (Portuguese plaintiffs); Delgado v. Shell Oil Co., 890 F. Supp. 1324 (S.D. Tex. 1995); Chambers v. MerrellDow Pharmaceuticals, Inc., 35 Ohio St. 2d 123, 519 N.E.2d 370 (1988).

63. Banco Latino v. Lopez, 18 F. Supp. 2d 1327 (S.D. Fla. 1998); Haddad v. Richardson-Merrell, 588 F. Supp. 1158 (N.D. Ohio 1984).

64. Piper Aircraft Co. v. Reyno, 454 U.S. 235, 247 (1981); Alfadda v. Fenn, 159 F. 3d 41 (2d Cir. 1998); Fitzgerald v. Texaco, Inc., 521 F.2d 448 (2d Cir. 1975). Cf. Canada Malting Co. v. Paterson S.S., Ltd., 285 U.S. 413 (1932); Murray v. British Broadcasting Co., 81 F.3d 287, 296 (2d Cir. 1996).

65. See Robertson, "Forum Non Conveniens in America and England: A Rather Fantastic Vision," 103 L.Q.R. 398 (1987). 
time for a year or more. The burdens, delays, and inconvenience to the other civil and criminal litigants ... would be enormous. This court's docket would be thrown into chaos.

In addition, this judge emphasized the heavy jury duty imposed on citizens for the complex trial, as well as, the difficulties of contending with foreign law. ${ }^{66}$

In In re Silicon Gel Breast Implant Prods. Liability Litigation, the trial court noted:

Another public interest factor supporting dismissal relates to the burden that litigation of these foreign claims would impose on courts in this country. In just these few actions, more than 1,000 foreign claimants are joined as named plaintiffs, and more than 100,000 others are included as members of a putative class. It is no answer that the evidence on behalf of these claimants relating to the culpability of the numerous defendants or to issues of "general causation" may mirror that presented in litigation by domestic plaintiffs ... it is clear that many, many trials involving this "common evidence" will be needed - with the time required for presentation of such evidence at each trial consuming weeks or even months. Moreover, even if some aggregate of claims should be found acceptable for trial of these of some of these common issues, the special questions regarding implantation, medical history, medical treatment, injuries, and specific causation would add many days of trial for each individual litigant. ${ }^{67}$

This concern strongly reinforces the numerous private interest factors inherently involved in any domestic trial involving events abroad involving foreign parties that from the outset exert a powerful pressure calling for application of $F N C$ in international human rights litigation. ${ }^{68}$

66. Orchimex de Costa Rico, S.A. v. E.I. DuPont de Nemours \& Co., 896 F. Supp 1197, 1201 (M.D. Fla. 1995); 896 F. Supp. 1197, 1202 (M.D. Fla. 1995) (fungicide damage to crops of Latin American commercial growers).

In still another fungicide litigation involving commercial Latin American shrimp farmers, a Florida state court applied its Supreme Court's guidance:

The use of Florida courts to police activities even in the remotest parts of the globe is not a purpose for which our judiciary was created. Florida courts exist to judge matters with significant impact upon Florida's interests, especially in light of the fact that the taxpayers of this state pay for the operation of its judiciary. Nothing in our Constitution compels the taxpayers to spend their money even for the rankest forum shopping by out-of-state interests. Ciba Geigy Ltd. v. The Fish Peddler, Inc., 691 So.2d 1111, 1113 (Fla Dist. Ct App. 1996) quoting Kinney Sys., Inc. v. Continental Ins. Co., 674 So.2d 86 (Fla. 1996).

67. In re Silicon Gel Breast Implant Prods. Liability Litig., 897 F. Supp. 1469, 1476 (N.D. Ala. 1995).

68. See also Delgado v. Shell Oil Co., 890 F. Supp. 1324, 1368 (S.D. Tex. 1995) (with 16,000 individual plaintiffs, judge devoting undivided attention to trial of the 
FNC litigation has included a wide spectrum of the law. The early prominent cases including Piper itself involved product liability for aircraft involved in air disasters. These presented no issues of international human rights. ${ }^{69}$ However, numerous $F N C$ cases have since involved international human rights. These have involved large groups of foreign residents. They include actions against American multinationals in the catastrophic tort liability litigation in the Bhopal disaster, numerous cases involving complaints by foreign consumers of injuries from allegedly dangerously defective drugs sold by large pharmaceutical corporate groups; worker complaints of substandard working conditions impairing the health of plant or agricultural employees; complaints of indigenous persons of allegedly dangerous environmental injuries; and complaints of indigenous persons for forced labor.

The $F N C$ cases involving American-based multinational enterprises have overwhelmingly involved the direct tort liability of American parent corporations subject to the local jurisdiction. Accordingly, there has been little need for the courts to consider the use of enterprise principles for the purpose either of establishing jurisdiction or underlying substantive liability. Although in some of the drug cases, foreign subsidiaries occupied a secondary role in the facts, this factor does not seem to have played any significant role in determining the outcome of such cases. ${ }^{70}$

(a) The Drug Cases. Of the FNC litigation involving international human rights, most of the cases involving the application of FNC to multinational corporations have involved the direct liability of American parent corporations of pharmaceutical groups to foreign residents for their own negligence in the design, manufacture, or testing in the United States of allegedly defective products causing injury abroad to foreign consumers. Enterprise liability has not been

action "would take more than a decade to hear the causation and damage issues alone"), aff'd 231 F.3d 165 ( $5^{\text {th }}$ Cir. 2000).

69. Human rights matters must be distinguished from the general run of tort cases. While cases involving alleged forced labor, massive environmental abuse, or mass catastrophes such as Bhopal may readily be classified as violations of basic human rights, some product liability issues present a more difficult case. Defective drugs, pesticides, and fungicides or other mass catastrophes affecting wide areas and many workers or consumers also have clear human rights implication, but what of aircraft crashes? Because of the limited numbers of persons affected and the presence of possible alternative causes for the injury unrelated to multinational conduct such as defective local maintenance, weather conditions, and pilot error, this paper does not discuss aircraft crashes. However, it should be noted that aircraft crash cases, such as Piper, have played a role in a shaping the general doctrine applied to human rights tort litigation as well.

70. E.g., Dowling v. Richardson-Merrell, Inc., 727 F.2d 608 (6th Cir. 1984) (foreign subsidiary acting as distributor for American parent manufacturer); Harrison v. Wyeth Labs. Div'n, 510 F. Supp. 1 (E.D. Pa. 1980) (production and marketing decisions made by American parent not English subsidiary), affd mem. 676 F.2d 685 (3d Cir. 1982). 
involved. Nor have jurisdiction or proof of the parent's participation in at least some of the conduct in issue raised any real difficulties in sharp contrast to international human rights litigation in other areas. In these cases, reflecting the fact-intensive nature of application of the doctrine and the wide area of discretion open to the trial court, the courts have sharply divided on their outcomes, notwithstanding their general agreement on the principles to be applied.

Thus, many of the drug decisions rejecting $F N C$ have been cases in which the design, manufacturing, or testing of the defective product occurred in the United States. These cases present a strong pressure to hear the case in the United States. They involve allegations of the direct liability of the American parent for its own negligence allegedly occurring in the United States. ${ }^{71}$ In view of the American locus of the alleged negligence in such design, manufacture, or testing, the role of American witnesses assumes greater importance. Furthermore, the increased American aspects of the foreign injury is an increased pressure to conclude that American law governs, thereby relieving the court of the burden of applying foreign law. ${ }^{72}$ Nevertheless, even in this most appealing situation for allowing the action to proceed in the United States by reason of the alleged negligent design, manufacture or testing of the product occurring in the United States, the foreign identity of the plaintiff, the foreign locus of the accident and injury, and the availability of foreign evidence on these aspects of the matter have led an impressive number of cases to apply the $F N C$ doctrine and dismiss the case. These cases have given greater weight to the burdens imposed on the American judicial system, the interest of the foreign jurisdiction in such litigation, and the presence of foreign witnesses on the occurrence of the injury.

71. Compare different outcome in Sequihua v. Texaco, Inv., 847 F. Supp. 61 (S.D. Tex. 1994) (negligence in Ecuador; $F N C$ applied) with Jota v. Texaco, Inc., 157 F.3d 153 (2d Cir. 1998) (negligence in United States; $F N C$ rejected). However, on remand of the Jota litigation, the trial court again held the suit barred by FNC. Aguinda v. Texaco, Inc. 147 F. Supp. 2d 532 (S.D.N.Y. 2001).

72. Carlenstrope v. Merck \& Co., 819 F.2d 33 (3d Cir. 1987) (within discretion of trial court); Chan Tse Ming v. Cordis Corp., 704 F. Supp. 217 (S.D. Fla. 1989); Haddad v. Richardson-Merrell, Inc. 588 F. Supp. 1158 (N.D. Ohio 1984); Picketts v. International Playtex, Inc., 215 Conn. 490, 576 A.2d 518, 524 (Conn. 1990) (Peters, C.J.) (product manufactured and distributed in Canada by American company with its principal place of business in Connecticut); Holmes v. Syntex Labs., 156 Cal. App. 3d 372 (1984). However, Holmes was subsequently overruled in Stagvik v. Shiley Inc., 1 Cal. Rptr. (2d) 556 (1991).

Chan Tse Ming went further and stated that even if Hong Kong law applied, that this factor of itself was not sufficiently persuasive to require application of FNC. 704 F. Supp. at 200, relying on Nestle's Prods. (Malaya) Ltd. v. Osaka Shosen Kaisha, 175 F. Supp. 876, 877 (S.D.N.Y. 1959).

In Haddad, the court also relied on foreign court delays and the familiarity of American counsel with the litigation. Haddad v. Richardson-Merrell, Inc. $588 \mathrm{~F}$. Supp. 1158 (N.D. Ohio 1984). 
This has occurred prominently in cases involving English plaintiffs where English law was applicable. ${ }^{73}$ Dowling $v$. RichardsonMerrell, Inc. is a prominent example. In Dowling, the Court of Appeals for the Sixth Circuit in such a case pointed to the strong English public concern with respect to the mass injuries of the English victims and the heightened English interest in the litigation. The court suggested that such product liability matters presented a particularly strong case for hearing the matter where the injury occurred. ${ }^{74}$

In dismissing United States litigations of this nature, Dowling and a number of other courts applying or following the federal doctrine expressly held that the systemic limitations then existing in the English judicial system including the unavailability of legal aid and contingent fee arrangements at that time, either were not relevant or were outweighed by the other factors. ${ }^{75}$ These courts invoked FNC even though the allegedly defective products had been, designed, manufactured, and tested in the United States. ${ }^{76}$ In contrast, the Delaware Supreme Court applying the more restrictive standards of Delaware law, Ison v. E.I. DuPont de Nemours \& Co., ${ }^{77}$ reached a contrary result in a defective drug case without relying on any systemic limitations of the foreign forum. As discussed below, Delaware recognizes $F N C$ only when the defendant can establish "overwhelming hardship."

As the degree of involvement of American parent companies in these multinational enterprises in the process of design, manufacture, testing, and distribution of the products decreases, the balance of forces shifts. As the locus of the alleged parent corporation negligence moves abroad, the courts tend increasingly to dismiss the American actions in reliance on FNC. Where the defective drug has been tested or manufactured abroad or there have been defects in the marketing of the product abroad, including inadequate warnings as to its use, the cases have increasingly applied the doctrine and dismissed the American litigation.

73. E.g., Dowling v. Richardson-Merrell, Inc., 727 F.2d 608 (6th Cir. 1984); Harrison v. Wyeth Labs. Div'n, 510 F. Supp. 1 (E.D. Pa. 1980), aff'd mem., 675 F.2d 685 (3d Cir. 198 ); Hodson v. A.H. Robins, Inc., 528 F. Supp. 809 (E.D. Va. 1981), affd 714 F.2d 142 (4th Cir. 1983); Holmes v. Syntex Labs., 158 Cal. App. 3d 372 (1984) (FNC inappropriate where foreign law less favorable to plaintiff), overruled by, Stangvik v. Shiley, Inc., 1 Cal. Rptr. (2d) 556 (1991).

74. See Dowling v. Richardson-Merrell, Inc., 727 F.2d 608 (6th Cir. 1984).

75. See Dowling v. Richardson-Merrell, Inc., 727 F.2d 608 (6th Cir. 1984); Harrison v. Wyeth Labs. Div'n, 510 F. Supp. 1 (E.D. Pa. 1980), affd mem. 675 F.2d 685 (3d Cir. 198 ).

76. Dowling v. Richardson-Merrell, Inc., 727 F.2d 608 (6th Cir. 1984); Harrison v. Wyeth Labs. Div'n, 510 F. Supp. 1 (E.D. Pa. 1980), affd mem. 675 F.2d 685 (3d Cir. 198 ); Holmes v. Syntex Labs., 156 Cal. App. 3d 372 (1984). However, Holmes was subsequently overruled in Stagvik v. Shiley Inc., 1 Cal. Rptr. (2d) 556 (1991).

77. Ison v. E.I. DuPont de Nemours \& Co., 729 A.2d 832 (Del. 1999)(Veasey, C.J.). 
Delgado v. Shell Oil Co. provides an example of this type of case. This involved an action by numerous Latin American plaintiffs injured by the use in their native countries of an allegedly dangerous drug of an American multinational pharmaceutical company. The plaintiffs relied on the allegedly negligent conduct of the parent corporation abroad in the testing and inadequate warning in marketing the product in Latin America. The court found that evidence was more readily available abroad and invoked FNC to dismiss the action. In so doing, the Court of Appeals for the Fifth Circuit brushed aside such systemic deficiencies in the Latin legal systems as the unfamiliarity of the jurisdictions with product liability matters, the inadequacy of their tort law, and the absence of contingent fee arrangements. ${ }^{78}$

(b) Mass Catastrophe. This involved a massive industrial catastrophe in Bhopal, India that is one of the most severe in history. As a result of the release of toxic fumes from the plant of the 50.9 percent owned Indian subsidiary of the American multinational, Union Carbide Corp., more than 2,000 people were killed and 200,000 injured. Plaintiffs relied almost entirely of allegations of the direct tort liability of the American parent, but included a final count asserting the parent corporation's vicarious liability for the negligence of the Indian subsidiary based on its enterprise liability as an integrated multinational enterprise. ${ }^{79}$ This count played no apparent role in the decision. Numerous class actions involving claims for the catastrophe against the American parent corporation were instituted in the United States, but were eventually consolidated. The Government of India was substituted as plaintiff representing the victims. Union Carbide moved to dismiss for $F N C$, and the Government of India opposed stressing the limitations of its own legal system.

Applying the analysis provided by Piper, the district court concluded that both the private and public interest factors supported dismissal. It concluded that the Indian courts had the capacity to deal with the complex litigation and that India provided an adequate al-

78. Delgado v. Shell Oil Co., 890 F. Supp. 1324 (S.D. Tex. 1995), affd, 231 F.3d 165 ( $5^{\text {th }}$ Cir. 2000). The court relied on Baumgart v. Fairchild Aircraft Corp., 981 F.2d 824, 835 (5th Cir. 1993)(aircraft crash) and Coates v. Arabian Am. Oil Co., 831 F.2d $572,575-76$ (5th Cir. 1987) (single employee), affd 231 F.2d 165 (5 $5^{\text {th }}$ Cir. 2001).

79. See Government of India v. Union Carbide Corp., No. 85 Civ. 2696 (S.D.N.Y. May 1985) (Complaint, "Count No. I: Multinational Enterprise Liability").

In Amoco Cadiz Oil Spill, 1984 A.M.C. 2123 (N.D. Ill. 1984), the court, after imposing direct tort liability on the part of the parent in a series of findings also imposed liability on a similar theory of enterprise law:

Conclusion of Law 43. "As an integrated multinational corporation which is engaged through a system of subsidiaries in the exploration, production, refining, transportation and sale of petroleum products throughout the world, standard [the American parent corporation] is responsible for the tortious acts of its wholly owned subsidiaries and instrumentalities AIC and Transport." 
ternative forum. It dismissed the complaint under $F N C$ on condition that (1) the defendant consent to Indian jurisdiction and waive any statute of limitations; (2) satisfy any judgment if comporting with "minimal requirements" of due process; (3) the defendant consent to discovery in accordance with the Federal Rules. ${ }^{80}$ On appeal, the Government of India reversed its position and sought to uphold the lower court's order.

The Court of Appeals for the Second Circuit commended the "well-reasoned" opinion of the lower court and applied much the same analysis. Emphasizing the private interest factors, it noted that the "vast majority" of witnesses and documentary proof bearing on causality and damages were both located in India and involved Hindi or other Indian languages. Without discussing whether public interest factors pointed the other way, it affirmed dismissal.

However, the Court of Appeals rejected the condition relating to satisfaction of the judgment, noting that the objective was better served by the provisions of New York law relating to enforcement of foreign judgments. It modified the discovery order to provide for consent to reciprocal discovery under the Federal Rules if so ordered by the Indian court. There was no indication by the court that the dramatic public prominence of the litigation and the fact that a subsidiary of an American multinational group was involved constituted a factor to be considered under the public interest elements being evaluated.

(c) Unsafe Working Conditions. Public interest groups have more recently been conducting American public relations campaigns over unsafe working conditions and substandard pay affecting workers employed in the foreign operations of American multinationals. In Torres v. Southern Peru Copper Co. ${ }^{81} 700$ Peruvian employees of a corporation incorporated in the United States but with its principal office abroad sued their employer for injuries allegedly arising from the emission of sulphur dioxide gas at the Peruvian plant of the multinational. While the American parent was allegedly directly responsible for the alleged tort, the conduct complained of occurred entirely in Peru. Further, the Peruvian Government opposed the prosecution of the litigation of the United States. With no American links to the alleged tortious conduct other than the American identity of the de-

80. In re Union Carbide Corp. Gas Plant Disaster at Bhopal, India in Dec. 1984, 634 F. Supp. 842 (S.D.N.Y. 1986), affd in part, rev'd in part, 809 F.2d 195 (2d Cir. 1987), cert. denied sub nom. Executive Committee Members v. Union of India, 484 U.S. 871 (1987).

81. Torres v. Southern Peru Copper Co., 965 F. Supp. 899 (S.D. Tex. 1996), affd 113 F.3d 540 (5th Cir. 1997). 
fendant, the court had little difficulty in dismissing the action citing both $F N C$ and comity. ${ }^{82}$

Cabalceta v. Standard Fruit Co. and Delgado v. Shell Oil Co. presented very much the same factors centering on alleged negligence abroad and the applicability of foreign law; the courts similarly dismissed the actions under $F N C .^{83}$

(d) Environmental Injury. Class actions on behalf of large numbers of persons allegedly injured by environmental abuses of American multinationals is another area of activist litigation. ${ }^{84}$ Sequihua $v$. Texaco, Inc. ${ }^{85}$ is a class action that might have included as many as 500,000 Ecuadorian rainforest residents for alleged environmental contamination by the operations of an American oil company. As with Torres, the facts of the case had no involvement with the United States except for the American identity of the multinational defendant, and the Ecuadorian Government requested dismissal. Ecuador protested that the relief sought would have supplanted the Ecuadorian Ministry of Health. The court thereupon dismissed in reliance on $F N C$, and the Court of Appeals for the Fifth Circuit affirmed. ${ }^{86}$

Jota $v$. Texaco, Inc. is a companion case, also involving the same alleged environmental abuse in Ecuador. However, in the interval following Ecuadorian elections, Ecuador supported trial in the United States. ${ }^{87}$ Moreover, in Jota, counsel introduced two new elements. The Sequihua complaint alleged negligence occurring abroad. In Jota, however, the plaintiffs also relied on the American parent's alleged conduct in the United States. Further, counsel relied not only on general tort liability but on the Alien Tort Claims Act (ATCA) as well. In view of these additional factors not considered in Sequihua, the Court of Appeals remanded the case to the district court for consideration. Jota is discussed in the following section dealing with litigation under the ATCA.

3. FNC and Litigation under the Alien Tort Claims Act (ATCA) and the Torture Victims Protection Act (TVPA)

As we have seen, the general application of the traditional private interest and public interest factors in applying $F N C$ doctrines to

82. Torres v. Southern Peru Copper Co., 965 F. Supp. 899 (S.D. Tex. 1996), affd 113 F.3d 540 (5th Cir. 1997).

83. Cabalceta v. Standard Fruit Co., 667 F. Supp. 833 (S.D. Fla. 1987); Delgado v. Shell Oil Co., 890 F. Supp. 1324 (S.D. Tex. 1995), affd 231 F.3d $165\left(5^{\text {th }}\right.$ Cir. 2001).

84. E.g., Jota v. Texaco, Inc., 157 F.3d (2d Cir. 1998), remanding Aguinda v. Texaco, Inc., 945 F. Supp. 61 (S.D. Tex. 1994).

85. Sequihua v. Texaco, Inc., 847 F. Supp. 61 (S.D. Tex. 1994).

86. Sequihua v. Texaco, Inc., 847 F. Supp. 61 (S.D. Tex. 1994).

87. Jota v. Texaco, Inc., 157 F.3d 153 (2d Cir. 1998), remanding Aguinda v. Texaco, Inc., 945 F. Supp. 625 (S.D.N.Y. 1996) on remand sub nom. Aguinda v. Texaco, Inc., 142 F. Supp. $2 \mathrm{~d} 532$ (District Court again applies $F N C$ ). 
foreign torts have strongly influenced the courts to refer the litigation to foreign tribunals. The fact that human rights were involved made no discernible difference. Until recently, no American court nor any judge (except for the dicta of a lone Texas intermediate appellate judge) seems to have into account whether the fact that violations of human rights had been alleged imposed on the American society and its legal system any special concern for providing an American forum to adjudge the conduct of American multinational enterprise. ${ }^{88}$ None had rejected $F N C$ dismissal for this reason.

This picture has changed somewhat. In two cases arising under the Alien Tort Claims Act (ATCA) and the Torture Victims Protection Act (TVPA), the Court of Appeals for the Second Circuit has introduced the statutory policy evidenced by the statutes as an entirely new element in the calculus as expressions of American public policy to be considered in the public interest evaluation. This element is lacking in the international human rights decisions applying $F N C$ to cases involving foreign torts generally.

The Statutes. The Alien Tort Claims Act (ATCA) ${ }^{89}$ provides federal subject matter jurisdiction ${ }^{90}$ when three factors have been satisfied: (1) the plaintiff is an alien; (2) the grievance is a tort; and (3) the tort has been committed in violation of the law of nations. The Torture Victims Protection Act (TVPA) ${ }^{91}$ is a companion statute providing a federal civil remedy for individuals who have been subjected to torture.

The statutes, thus, have a highly restricted scope. Only when a violation of the law of nations or customary international law ${ }^{92}$ can be established, do they apply. ${ }^{93}$ The courts have begun to resolve three threshold issues. They have addressed the issue of which torts constitute violations of the law of nations. In the landmark case, $F i$ lartiga $v$. Pena-Irala, the Court of Appeals for the Second Circuit held that state torture violated the law of nations and was covered by the ATCA. ${ }^{94}$ They have held that unpaid, forced labor was the

88. See Doggett, J, concurring, in Dow Chem. Co. v. Alfaro, 786 S.W.2d 674, 680 (Tex. Ct. App. 1990), cert. denied, 498 U.S. 1024 (1991). See also supra n. 37 infra.

89. 28 U.S.C. $\$ 1350$ (2001).

90. Since suits under ATCA involve a federal statute, federal subject matter jurisdiction is available. However, in the case of tortious conduct resulting in other human rights violations not covered by ATCA, litigation must proceed in the state courts unless diversity of citizenship can be established.

91. Pub. L. 102-256, Mar. 12, 1992, 106 Stat. 73; 28 U.S.C. $\$ 1350$ (2001).

92. The terms "law of nations" and "customary international law" are deemed interchangeable. See Iwanova v. Ford Motor Co., 67 F. Supp. 2d 424 (D.N.J. 1999); Siderman de Blake v. Reppublic of Argentina, 965 F.2d 699, 715 (9 ${ }^{\text {th }}$ Cir. 1992); Sanchez-Espinoza v. Reagan, 770 F.2d 202, 206 (D.C. Cir. 1985).

93. Some courts have said that the ATCA only applies to "egregious or shocking" violations of international law. Beanal v. Freeport-McMoran, Inc., 197 F.3d 161, 166 (5 ${ }^{\text {th }}$ Cir. 1999); Zapata v. Quinn, 707 F.2d 691, 692 (2d Cir. 1983) (per curium).

94. Filartiga v. Pena-Irala, 630 F.2d 876 (2d Cir. 1980). 
equivalent of the slave trade, long condemned by the law of nations. ${ }^{95}$ They have similarly held that war crimes in Bosnia-Herzgovina were covered by the ATCA and violated the law of nations. ${ }^{96}$ One commentary has also included summary execution; genocide; war crimes; disappearance; arbitrary detention; and cruel, degrading treatment as constituting violations and goes on to suggest cautiously that serious environmental abuse might also be included. ${ }^{97}$

Second, in cases involving alleged war crimes, slave-trading and forced labor, they have held that the law of nations binds private actors, as well as states. ${ }^{98}$

Finally, they have held that a private right of action under ATCA exists for violations of the law of nations, ${ }^{99}$ making possible the wave of human rights litigation under the statute that is emerging. Although these issues of substantive law are of grave importance, they are beyond the scope of this paper.

The Cases. The Court of Appeal for the Second Circuit is the only American appellate court to consider the application of $F N C$ in litigation under the ATCA. ${ }^{100}$ While the Courts of Appeal for the Fifth and Ninth Circuits and other courts have also considered international human rights cases under the ATCA, those decisions did not involve FNC. ${ }^{101}$

95. Iwanova v. Ford Motor Co., 67 F. Supp. 2d 424 (D.N.J. 1999); Doe v. Unocal Corp., 248 F.3d 915 ( $9^{\text {th }}$ Cir. 2001); Princz v. Federal Republic of Germany, 26 F.3d 1166, 1180 (D.C. Cir. 1994) (Wald, J. dissenting); Tel.-Oren v. Libyan Arab Republic, 726 F.2d 774, 781 (D.C. Cir. 1984) per curiam (Edwards, J. concurring); National Coalition Gov't of the Union of Burma v. Unocal, Inc., 176 F.R.D. 329, 349 (C.D. Cal. 1997).

96. Kadic v. Karadzic, 70 F.3d 232, 239, 244-45 (2d Cir. 1995).

97. B. Stephens \& M. Ratner, International Human Rights Violations Litigation in U.S. Courts 63-94 (1996). See Beanal v. Freeport-McMoran, Inc., 197 F.3d 161 (5 $^{\text {th }}$ Cir. 1999).

98. Kadic v. Karazdic, 70 F.3d 232 (2d Cir. 1995) (Newman, C.J.). See Iwanova v. Ford Motor Co., 67 F. Supp. 2d 424 (D.N.J. 1999). Unlike the ATCA, the TVPA expressly provides for an individual cause of action. Pub. L. 102-256, Mar. 12, 1992, 106 Stat. 73 , sec. 2(a).

99. Jama v. Immigration \& Naturalization Serv., 22 F. Supp. 2d 353, 362-63 (D.N.J. 1998); Abebe-Jira v. Negewo, 72 F.3d 844, 848 (11 $1^{\text {th }}$ Cir. 1996); Kadic v. Karazdic, 70 F.3d 232 (2d Cir. 1995) (Newman, C.J.); Iwanova v. Ford Motor Co., 67 F. Supp. 2d 424, 443 (D.N.J. 1999). But see Tel-Oren v. Libyan Arab Republic, 726 F.2d 781, 810-26 (D.C Cir. 1984) (Bork, J. concurring).

100. Jota v. Texaco, Inc., 157 F.3d 153 (2d Cir. 1998) (Newman, C.J.), rev'g Aguinda v. Texaco, Inc., 945 F. Supp. 625 (S.D. N.Y. 1996), on remand, 139 F. Supp. 2d 139, 438 (S.D.N.Y. 2000), 142 F. Supp. 2d 533 (S.D.N.Y. 2001) (dismissing complaint). District court decisions involving FNC under the ATCA include involved alleged environmental abuses, human rights abuses, and cultural genocide in Indonesia.

101. Beanal v. Freeport-McMoran, Inc., 197 F.3d 161 ( $5^{\text {th }}$ Cir. 1999)( alleged environmental abuses, human rights violations, and cultural genocide); Doe v. Unocal Corp., 248 F.3d 915 ( $9^{\text {th }}$ Cir. 2001) (alleged forced labor in Burma); Iwanowa v. Ford Motor Co., 67 F. Supp. 2d 424 (D.N.J. 1999) (forced labor by Ford at its subsidiary's plant in Nazi Germamy during World War II). 
Jota $v$. Texaco, Inc. ${ }^{102}$ was a consolidated appeal of two cases under the ATCA on behalf of indigenous tribes in Ecuador for environmental and personal injuries allegedly resulting from Texaco's oil operations. As noted, it was a companion case to Sequihua involving much the same facts but resting solely on allegations of general tort liability. In Jota, the district court ${ }^{103}$ dismissed the action under FNC adopting the findings in Sequihua v. Texaco. ${ }^{104}$ On appeal, the Court of Appeals held that the district court improperly failed to condition its action on a commitment by Texaco to submit to the jurisdiction of Ecuador. In addition, the court noted two factors present in Jota that distinguished it from Sequihua and made the trial court's sole reliance on the findings in Sequihua inappropriate. Unlike Sequihua, Jota was brought under ATCA as well as under general tort law. Further, plaintiffs rested their case entirely on the conduct of Texaco in the United States, thereby providing ready access to the necessary documents and witnesses.

In consequence, the court, while expressing "no view" on these two distinctions,

recognized the plaintiff's argument that to dismiss . . . a claim pursuant to the ATCA under forum non conveniens would frustrate Congress's intent to provide a federal forum for aliens suing domestic entities for violations of the law of nations. ${ }^{105}$

It revised and remanded the case to the district court for reconsideration of the forum non conveniens issue. ${ }^{106}$ The court added:

We express no view on whether the plaintiffs have alleged conduct by Texaco that violates the law of nations, whether an ATCA suit for environmental misconduct, alleged to violate the law of nations, may be brought against a non-governmental entity under the ATA, or how the forum non conveniens balance for ATA claims is to be struck when alien plaintiffs select a United States forum for a suit against a domestic corporation. ${ }^{107}$

All this did not lead to a different outcome. On remand, the district court again dismissed the action under FNC. ${ }^{108}$

102. 157 F.3d 153 (2d Cir, 1998) (Newman C.J.).

103. Aguinda v. Texaco, Inc., 945 F. Supp. 625 (S.D.N.Y. 1996), rev'd sub nom. Jota v. Texaco, Inc., 157 F.3d (2d Cir. 1998).

104. Sequihua v. Texaco, Inc., 847 F. Supp. 61 (S.D. Tex. 1994) (dismissing under FNC and comity).

105. See Wiwa v. Royal Dutch Petroleum Co., 226 F.3d 88 (2d Cir. 2000) (Leval, J.); Jota v. Texaco, Inc., 157 F.3d 153 (2d Cir. 1998 ).

106. 157 F.3d at 158 .

107. 157 F. $3 \mathrm{~d}$ at 158 n. 6.

108. Aguinda v. Texaco, Inc., 147 F. Supp. 2d 532 (S.D.N.Y. 2001). 
Wiwa v. Royal Dutch Petroleum Co., ${ }^{109}$ decided two years later; was an action under the ATCA and TVPA against the Anglo-Dutch multinational, Royal Dutch Petroleum/Shell, for participation with the Nigerian government in alleged grave human rights violations in Nigeria involving forced labor as well as torture.

In a decision resting solely on the general $F N C$ private/public interest factor analysis, the district court dismissed the action. The Court of Appeals reversed, again singling out two factors of special significance. First, the court focused on the unusual circumstance that two of the Nigerian plaintiffs were refugees and legally resident in the United States. ${ }^{110}$ The Court invoked its decision in Guidiv, Inter-Continental Hotels Corp., decided several years earlier, involving a common law tort action for injuries and death suffered by Americans in an Egyptian terrorist shooting. ${ }^{111}$ In Guidi, the court had ruled that a resident plaintiff's choice of forum should receive "heightened deference" and should be "rarely disturbed." Further, the court emphasized the role of the ATCA and the TVPA in evaluating the American public interest in the litigation.

The Court of Appeals held that:

as a matter of law, in balancing the competing interests, the district court did not accord proper significance to a choice of forum by lawful U.S. residents or to a policy interest implicit in our federal statutory law in providing a forum for adjudication of claims of violations of the law of nations. ${ }^{112}$

It accepted the plaintiffs argument that these statutes reflected a United States policy in providing a forum for the adjudication of international human rights issues and that this policy interest should have a role in the balancing of the traditional factors. It also held that the factors that led the district court to favor a British forum were not "particularly compelling" and that the court below had failed to give adequate consideration to the "enormous burden, expense, and difficulties plaintiffs would suffer if required to being the litigation anew in England."

It then limited its holding, stating:

This is not to suggest that the TVPA has nullified, or even significantly diminished, the doctrine of forum non conveniens. The statute, however, has communicated a policy that such suits should not be facilely dismissed on the assumption that the ostensibly foreign controversy is not our business. The TVPA in our view expresses a policy favoring

109. 226 F.3d 88 (2d Cir. 2000) (Leval J.).

110. Wiwa involving two Nigerian refugees now residing in the United States is an exception. Wiwa v. Royal Dutch Petroleum Co., 226 F.3d 88 (2d Cir. 2000).

111. Guidi v. Inter-Continental hotels, Corp., 224, F.3d 142 (2d Cir. 2000).

112. 226 F.3d at 99 . 
our courts' exercise of the jurisdiction conferred by the ATCA in cases of torture unless the defendant has fully met the burden of showing that the Gilbert factors "tilt strongly" in favor of trial in the foreign forum. ${ }^{113}$

The Court's decision represents a substantial advance in the procedural jurisprudence involved in the application of $F N C$ in international human rights cases arising under the TVPA. It pointed out that the TVPA "conveyed the message" that claims such as involved in Wiwa were "our business" and that the legislative history of the Act "supports plaintiff's contention" that in passing the Act, "Congress has expressed a policy of U.S. law favoring the adjudication of such suits in U.S. courts. "114 It further highlighted the significance of United States residence on the part of the plaintiff. The opinion in Wiwa and the opinion in Jota underscoring the significance of allegations of parent corporation misconduct within the United States will undoubtedly play an important role in shaping counsel's presentation of future international human rights cases.

Judge Leval's opinion in Wiwa introduces into the jurisprudential consideration factors of considerable significance creating powerful pressures for an American hearing of international human rights matters. In all such litigation, American residence of the plaintiffs clearly changes the calculus. Further, the court's emphasis on the "burden, expense, and difficulties" of suit abroad gives heightened importance to that factor. Finally, in the special area of suits under the ATCA and the TVPA, the statutory policy in favor of an American hearing discerned by the Court creates a strong additional factor for rejection of $F N C$.

The precedential influence of Wiwa is restricted by Judge Leval's emphasis on the TVPA. This is a serious limitation in any effort to rely on the decision in cases arising under the ATCA that do not involve torture and even more so in the cases alleging common-law torts. Nevertheless, even in that circumstance, the Court of Appeals in Jota underscored the public policy expressed by ATCA as a factor that had to be taken into account in evaluating the so-called public interest factors militating against application of $F N C$. It would appear that the very enactment of the ATCA demonstrates the Congressional recognition of the importance of such litigation to the American society and supports the case for an American hearing, even if not as significantly as when supported by the TVPA as well.

The TVPA, ATCA and the Second Circuit decisions introduce powerful new factors in the consideration of the application of $F N C$ in all cases of alleged human rights violations by American multination-

113. 226 F.3d at 100, 105 citing R. Maganlal \& Co. v. M. G. Chem . Co., 942 F.2d 164, 167 (2d Cir. 1991).

114. 226 F.3d at 105 . 
als. They change the calculus of evaluation of the applicability, strongly reinforcing the public interest in providing a hearing of such cases in the United States. In Judge Leval's striking words, it is now much harder to conclude that such matters are not "our business."

In summary, these important developments in the Second Circuit must be placed in perspective. In the first place, they are applicable only to litigation involving ATCA and TVPA, both of which have a restricted scope. The ATCA only applies to violations of "the law of nations" or customary international law, and in the case of the TVPA, only to cases of torture. At the present stage of development, it is far from clear what alleged violations of human rights by multinationals may be considered to constitute offenses against the law of nations. This very issue presents one of the major jurisprudential problems facing the nations of the world.

While the law, at least in the Second Circuit, appears to be changing, the course of future judicial development still remains to be seen. It is still far from clear to what extent in the gestalt of FNC decision-making, the new doctrines will in fact lead to a different outcome in the litigation. The aftermath in the Jota litigation is not encouraging. Further, it is far from evident whether other Courts of Appeal are prepared to lower the barriers of FNC and to follow the lead of the Second Circuit in cases under the ATCA and TVPA. Further, it is problematic whether, as the law evolves, the courts will regard the public policy discerned by the Second Circuit in the ATCA and the TVPA in favor of an American forum to extend to FNC litigation involving international human rights abuses that do not violate international law and are not brought under ATCA. This includes the substantial body of $F N C$ international human rights litigation to date involving mass catastrophes and defective drug, fungicide, and pesticide cases and environmental pollution cases (if those indeed are ultimately held not to be violations of international law).

With the increasing role of international human rights in international law and American foreign policy, American law dealing with forum non conveniens may be expected to be more sympathetic to providing an American forum for alleged violations abroad by constituent companies of American-based multinational groups. This is particularly likely to be so when the suit includes American residents among the plaintiffs and involves allegations of participation in the United States by the American parent corporation in the conduct in issue. However, there are powerful pressures for applying $F N C$ as the acts complained of involve events abroad with foreign witnesses, foreign evidence, and foreign law. Finally, the great concern in the American judiciary with the problems of overcrowding and delayed dockets already existing in the United States gives a final powerful reinforcement to the forces making for dismissal of the actions. 


\section{Judicial Efforts to Ameliorate The Consequences of FNC Dismissal}

As noted, FNC may not lead to dismissal unless there is an alternative adequate foreign forum. Reflecting this principle, American courts have widely insisted on consent or stipulation by the defendant to strengthen the availability and adequacy of the foreign form.

The primary concern is to confirm that the foreign forum has in personam jurisdiction over the defendants so as to assure that the foreign forum is in fact available. In contrast to England, ${ }^{115}$ the fact that foreign in personam jurisdiction may not exist at the time of institution of the litigation is not viewed as decisive in the United States. ${ }^{116}$ American courts in $F N C$ litigation have recognized two alternative solutions permitting application of the doctrine of $F N C$. The defendant may undertake to consent to the foreign jurisdiction ${ }^{117}$ or as many American courts have done, the court may condition its action dismissing the complaint for $F N C$ on the defendant agreeing to do so. ${ }^{118}$ In a similar manner, to assure the adequacy of the foreign remedy, American courts have taken a wide array of other actions. They have conditioned their actions dismissing an action in reliance on $F N C$ on similar consents by the defendants to waive the statute of limitations ${ }^{119}$ and to undertake to allow broad discovery and make

115. In Sithole and Lubbe, the English courts found that the absence of such jurisdiction at the time of commencement of the action in England was an important factor in refusing to grant the defendant's motion. The defendant's subsequent undertaking to submit to the foreign jurisdiction was not sufficient. The courts were not inclined to compel the foreign plaintiff to sue in the foreign forum that was not available to him when it brought suit in England. Compare Sithole v. Thor Chem. Holdings Ltd., No. JC 98 649, 749,798 (Q.B.D. July 31, 1998); Lubbe v. Cape, plc. (C.A. July 30, 1998).

116. See Schertenlieb v. Frauen, 589 F.2d 1156 (2d Cir. 1978). Cf. Piper Aircraft Co. v. Reyno, 454 U.S. 235 ( $s u b$ silentio).

117. Jota v. Texaco, Inc., 157 F.3d 153 (2d Cir. 1998), remanding Aguinda v. Texaco, Inc., 945 F. Supp, 625 (S.D.N.Y. 1996); Magnin v. Teledyne Continental Motors, 91 F.3d 1424 (11th Cir. 1996).

118. E.g., Magnin v. Teledyne Continental Motors, 91 F.3d 1424 (11th Cir. 1996); Macedo v. Boeing Co., 693 F.2d 983 (7th Cir. 1982); Aguinda v. Texaco, Inc., 945 F. Supp, 625 (S.D.N.Y. 1996), rev'd on other grounds sub nom. Jota v. Texaco, Inc., 157 F.3d 153 (1998); Banco Latino v. Lopez, 18 F. Supp. 2d 1327 (S.D. Fla. 1998); Nolan v. Boeing Co., 919 F.2d 1058 (5th Cir. 1990); ); Watson v. Merrell-Dow Pharmaceuticals, Inc., 769 F.2d 354 (6th Cir. 1985). Delgado v. Shell Oil Co., 890 F. Supp. 1324 (S.D. Tex. 1995); In re Union Carbide Corp. Gas Plant Disaster at Bhopal, India in Dec. 1984,634 F. Supp. 842 (S.D.N.Y. 1986), affd in part, rev'd in part, 809 F.2d 195 (2d Cir. 1987), cert. denied sub nom. Executive Committee Members v. Union of India, 484 U.S. 871 (1987); Chambers v. Merrell-Dow Pharmaceuticals, Inc., 35 Ohio St. 2d 123, 519 N.E.2d 370 (1988).

119. E.g., Magnin v. Teledyne Continental Motors, 91 F.3d 1424 (11th Cir. 1996); Macedo v. Boeing Co., 693 F.2d 983 (7th Cir. 1982); Aguinda v. Texaco, Inc., 945 F. Supp, 625 (S.D.N.Y. 1996), rev'd on other grounds sub nom. Jota v. Texaco, Inc., 157 F.3d 153 (1998); Banco Latino v. Lopez, 18 F. Supp. 2d 1327 (S.D. Fla. 1998); 1990); Watson v. Merrell-Dow Pharmaceuticals, Inc., 769 F.2d 354 (6th Cir. 1985). Delgado v. Shell Oil Co., 231 F.3d 165 ( $5^{\text {th }}$ Cir. 2000); Chambers v. Merrell-Dow Pharmaceuticals, Inc., 35 Ohio St. 2d 123, 519 N.E.2d 370 (1988). 
witnesses or documents available. ${ }^{120}$ They have also conditioned dismissal on consent to be bound or to satisfy the foreign judgment, or to have a related non-party corporation bound by the judgment. ${ }^{121}$

\section{State Law Variations in FNC Doctrine}

While the Piper and Gilbert analysis governs in the federal courts and is typically applied in most state litigation, ${ }^{122}$ the states are, of course, free to pursue their own course. Delaware, for one has done so. As recently expressed by Chief Judge Veasey in a case involving allegedly defective drugs creating birth defects in British and New Zealand children, he held that FNC may not be used to defeat a "plaintiff's choice of forum . . . except in the rare case where the defendant establishes . . . overwhelming hardship and inconvenience."123 The "overwhelming hardship and inconvenience" standard asserted in Delaware dramatically confines the scope of $F N C$. It is the most restrictive formulation of the doctrine in the United States. It is only exceeded by the isolated jurisdictions that

120. Magnin v. Teledyne Continental Motors, 91 F.3d 1424 (11th Cir. 1996); Aguinda v. Texaco, Inc., 147 F. Supp. 2d 532 (S.D.N.Y. 2001); Banco Latino v. Lopez, 18 F. Supp. 2d 1327 (S.D. Fla. 1998); Watson v. Merrell-Dow Pharmaceuticals, Inc., 769 F.2d 354 (6th Cir. 1985); Delgado v. Shell Oil Co., 231 F.3d 165 (5 $5^{\text {th }}$ Cir. 2000); Chambers v. Merrell-Dow Pharmaceuticals, Inc., 35 Ohio St. 2d 123, 519 N.E.2d 370 (1988).

121. In re Union Carbide Corp. Gas Plant Disaster at Bhopal, India in Dec. 1984, 809 F.2d 195 (2d Cir. 1987), cert. denied sub nom Executive committee Members v. Union of India, 484 U.S. 871 (1987); Banco Latino v. Lopeze, 18 F. Supp. 2d 1327 (S.D. Fla. 1998); Chambers v. Merrell-Dow Pharmaceuticals, Inc., 35 Ohio St. 3d 123, 519 N.E.2d 370 (1988).

122. E.g. Chambers v. Merrell-Dow Pharmaceuticals, Inc., 35 Ohio St. 2d 123, 519 N.E.2d 370 (1988); Atchison, T. \& S.F. Ry. v. District Ct., 298 P.2d 427 (Okla. 1956).

Most states have recognized the doctrine through statutory or common law. See Chambers v. Merrell-Dow Pharmaceuticals, Inc., 35 Ohio St. 2d 123, 519 N.E.2d 370 (1988). See also Robertson \& Spech, "Access to State Courts on Transnational Personal Injury Cases: Forum non Conveniens and Antisuit Injunctions," 68 Tex. L. Rev. 937, 950 n.74 (1990) (hereinafter cited as Robertson \& Spech); Solen.

However, in a number of states, the courts have altered the governing principles to make application more difficult. See, e.g., Ison v. E.I. DuPont de Nemours Inc., 729 A.2d 832 (Del. 1999) (Veasey, C.J.); Picketts v. International Playtex, Inc., 576 A.2d 518, 524 (Conn. 1990)(Peters, C.J.) (accepting doctrine in somewhat restricted form while finding facts made its exercise inappropriate); Holmes v. Syntex Labs., $156 \mathrm{Cal}$. App. 3d 372 (1984) (FNC inappropriate where foreign law less favorable). However, Holmes was subsequently overruled in Stangvik v. Shiley Inc., 1 Cal. Rptr. (2d) 556 (1991) (Mosk, J.).

See generally Litman, "Considerations of Choice of Law in the Doctrine of Forum Non Conveniens," 74 Calif. L. Rev. 565 (1986).

123. Ison v. E.I. DuPont de Nemours \& Co., 729 A.2d 832, 837, 847 (1999) ("The fact that DuPont's principal place of business is in Delaware and the fact that the product at issue was researched and developed in Delaware effectively preclude a finding on this record that DuPont would suffer overwhelming hardship by litigating in Delaware.") Although the decision rested on the facts, the analysis of Chief Justice Peters in Picketts v. International Playtex, Inc., 215 Conn. 490, 576 A.2d 518, 524-25 (1990), another international defective drug case, is in Chief Justice Veasey's expression "consistent" with the Delaware "overwhelming hardship language". $729 \mathrm{~A} .2 \mathrm{~d}$ at 842. 
do not recognize the doctrine. Only in Delaware, and perhaps in Connecticut ${ }^{124}$, has the state jurisprudence, while generally following the federal framework, taken a decisively different turn in its application.

There is a final dimension of the problem. Gilbert was decided a half-century ago. Further, it was a domestic litigation without any foreign aspects. Since that time, a technological revolution has occurred, dramatically changing the significance of some of the standards established in Gilbert and Piper. Jet travel, video depositions, satellite communications have fashioned a different reality for application of older standards of "private" interests, pertaining to the availability and presentation of evidence, convenience of the parties, witnesses, and counsel, and attendant consequences of time requirements and expense of travel. Distance is still an enemy but of significantly shrunken dimensions. ${ }^{25}$ This factor which largely contributed to the International Shoe "minimum contacts" revolution in the American law of in personam jurisdiction is rarely introduced into the cases considering the application of FNC. ${ }^{126}$

\section{Summary: FNC and Multinational Corporations}

As noted, the traditional FNC doctrine in the United States reflects entity law. Parent and subsidiary are separate juridical entities for $F N C$ as well as jurisdiction and joinder. Even in the case of a highly integrated multinational enterprise conducting a worldwide business under the public persona of the American parent corporation through numerous subsidiaries, domestic and foreign, operating under its control, the United States jurisprudence looks upon the foreign subsidiary as a separate juridical entity. In this area at least, American courts have, thus far, shown little, if any, disposition to discard traditional concepts of $F N C$ and entity law, except where there has been "substantial involvement" by the parent corporation in the tortious conduct in the United States. ${ }^{127}$ Even for purely procedural purposes of applying $F N C$, the American domicile of the parent corporation is irrelevant.

Except for the steps in the Second Circuit, the decided cases show little signs of change. To date, however, the world is changing,

124. Picketts v. International Playtex, Inc., 215 Conn. 490 , 576 A.2d 518, 524 (1990) (Peters, C.J.).

125. See Manu Int'l, S.A. v. Avon Prods., Inc, 641 F.2d 62, 65 (2d Cir. 1981); Calavo Growers v. Belgium, 632 F.2d 963 (2d Cir. 1980) (Newman, J., concurring) (pointing to "realities of modern transportation and communications"), cert. denied, 449 U.S. 1084 (1981); Fitzgerald v. Texaco, Inc., 521 F.2d 448, 45* (2d Cir. 1975) (Oakes, J.), cert. denied, 423 U.S. 1052 (1976).

126. For an apparent exception See Picketts v. International Playtex Inc., 215 Conn. 490, 576 A.2d 518 (1990) (Peters, C.J.).

127. See Birnbaum \& Dunham, "Foreign Plaintiffs and Forum Non Conveniens," 16 Brook. L. Rev. 241 (1991). 
and this inevitably will create forces making for change in the readiness of American judges to adapt the doctrine to reflect the increasing recognition of international human rights in the national and international legal systems. Sooner or later, courts will have to determine whether the fact that an American multinational enterprise is involved may itself constitute a factor of such importance that this factor should be added to the "public interest" factors evaluated in the $F N C$ calculus. Further, as has already been recognized in the Second Circuit, the presence of international human rights is a significant factor to be considered among the public interest factors to be taken into account by the trial courts where the action proceeds under the ATCA or TVPA. In the past, the private interest factors have dominated the judicial inquiry. This may well change with public interest factors increasing in importance reflecting the increasing prominence of the global economy in American thinking and the greater concern for international human rights on the world and national political scene. How far this undercurrent will lead to the evolution of a significantly increased readiness by American courts to give hearing to litigation by foreign plaintiffs involving foreign conduct of American multinationals is the question.

However, the pressures against change remain very strong. International human rights litigation inevitably means a predominance of conduct abroad, of foreign witnesses, and foreign evidence. These greatly strengthen the case for dismissal so long as courts continue to give great emphasis to the private interest factors enunciated in $\mathrm{Gil}$ bert and Piper. Further as noted, many courts are gravely concerned with problems of crowded dockets and existing pressures "to keep the judicial business moving." The burdens of handling such complex litigation involving thousands of plaintiffs in some cases, in an already overloaded system, are daunting.

In the end, this issue may ultimately be decided by the extent to which courts throughout the United States respond to globalization with a readiness to reshape legal doctrine to the changing world.

\section{Joinder and Federal Subject Matter Jurisdiction}

Federal Rules of Procedure dealing with the joinder of parties create still another procedural obstacle based on entity law to American suits by foreign plaintiffs in the federal courts against multinational corporations for their conduct abroad. Under the federal procedures requiring the joinder of parties found to be necessary and indispensable, the basis for diversity of citizenship jurisdiction of the federal courts may be destroyed.

Federal Rule of Procedure 19 creates this possible barrier to obtaining a federal hearing for any international human rights proceeding that rests on diversity of citizenship jurisdiction. Suits arising 
under a federal statute such as the Alien Tort Claims Act or the Torture Victim Protection Act provide their own subject matter jurisdiction and are not affected. Nor are suits in the state courts.

In diversity cases, subject matter jurisdiction of the federal courts arises when the foreign plaintiff and the American parent corporation have different citizenship. Since each party plaintiff must have different citizenship than each party defendant, the joinder of the foreign subsidiary as an additional party defendant in the action instituted by a foreign plaintiff destroys diversity. ${ }^{128}$ Under Rule 19, it may be possible for the defendant parent corporation to destroy diversity by seeking to have the court determine that the participation of the foreign subsidiary is necessary because of its involvement in the matters complained of and the resulting prejudice if not joined and that its participation as a party in the litigation is indispensable. Whether the parent corporation can satisfy the requirements of the Rule is another matter.

Rule 19 (a) provides for the joinder of additional parties closely related to the litigation upon satisfying certain standards specified in the provision. Where a parent defendant corporation seeking to take advantage of Rule 19 can demonstrate the necessary interest and involvement of the subsidiary in the litigation, the court may determine that the addition of the subsidiary is necessary and order that it be joined as party defendant. However, joinder is available only when it will not deprive the court of jurisdiction over the subject matter. Rule 19(b) provides that in such cases if the person in question cannot be made a party, "the court shall determine whether in equity and good conscience the action should proceed . . . or should be dismissed, the absent person being thus regarded as indispensable."129 Where the absent person viewed indispensable lacks the necessary diversity of citizenship from every party plaintiff, the federal court loses its subject matter jurisdiction and must dismiss the proceeding Aliens on both side of the litigation are fatal. ${ }^{130}$

Paradoxically, this means that in cases involving international corporate groups, an effort to have both members of the corporate group before the court - the foreign subsidiary as well as the American parent corporation - may result in a loss of federal subject matter

128. Strawbridge v. Curtiss, 7 U.S. (3 Cranch) 267 (1866); Ed and Fred, Inc. v. Puritan Marine Ins. Underwriting Corp., 506 F.2d 757 ( $5^{\text {th }}$ Cir. 1975); Cabalceta v. Standard Fruit Co., 883 F.2d 1553, 1556 (11 ${ }^{\text {th }}$ Cir. 1989); Polanco v. H.B. Fuller Co., 941 F. Supp. 1512, 1522 (D. Minn. 1996).

129. F. Rule of Civ. P. 19. See generally 8 C. Wright, A. Miller, \& M. Kane, Federal Practice and Procedure $\$ 1601$ et seq. (3d ed. 2001).

130. Polanco v. H.B. Fuller Co., 941 F. Supp. 1512 (D. Minn. 1996); Hoyt R. Matise Co. v. Zurn, 754 F.2d 560 ( $5^{\text {th }}$ Cir. 1985); Gay v. AVCO Fin. Servs., In., 769 F. Supp. 51 (D.P.R. 1991); E. \& E. Inv. Co. v. Simmons Co., 169 F.R.D. 467 (D.P.R. 467). See 28 U.S.C. $\$ 1332(a)$, (d). 
jurisdiction. In still another area, entity law may have unfortunate consequences in litigation involving corporate groups.

Polanco v. H. B. Fuller Co. ${ }^{131}$ illustrates how this doctrine may block access to the federal courts by foreign plaintiffs against American multinationals. Polanco was a wrongful death action against an American parent corporation on behalf of a Guatemalan decedent arising from the inhalation of liquid glue sold by the parent's 80 percent owned Guatemalan subsidiary. The subsidiary was not a party, and the defendant moved to join the subsidiary as an indispensable party in the litigation under Rule 19.

The court granted the motion. However, joining the Guatemalan subsidiary as a party defendant in an action by a Guatemalan party plaintiff made a foreign party on each side of the litigation destroying diversity of citizenship, and with it, federal subject matter jurisdiction. Even in the event of dismissal from the federal courts, litigation against the American parent corporation may still proceed in the courts of any state with in personam jurisdiction. However, counsel having brought suit in the federal court had already indicated its preference to conduct the litigation in the federal courts, not the state courts.

The perils presented by joinder and federal subject matter jurisdiction illustrated by Polanco have not arisen thus far in any of the international human rights litigation. This a future problem.

\section{Conclusion}

Concepts of the corporate juridical personality were developed in the Anglo-American legal system centuries ago to distinguish corporations from their stockholders. This is entity law. With the development in the last century of the holding company with its unlimited number of subsidiary and the formation of corporate groups, the law mistakenly failed to recognize that the older jurisprudence of entity law reinforced by the principle of limited liability no longer fairly served the newer economic society. Principles developed to shield investors from the debts of the corporation in which they were shareholders became largely dysfunctional when applied to multi-tiered corporate groups.

To the economist and the public, the multinational conducting its common business under common control through scores or hundreds of subsidiary companies throughout the world is a single enterprise. It is a single actor. It is the firm. However under entity law, it is atomized and unrealistically deemed for legal purposes to be scores or hundreds of separate corporations.

131. Polanco v. H.B. Fuller Co., 941 F. Supp. 1512 (D. Minn. 1996). See Freeman v. Northwest Acc. Corp., 742 F.2d 553 (5 $5^{\text {th }}$ Cir. 1985); Dou Yee Enterprises (S) PTE, Ltd. v. Advantek, 149 F.R.D. 185 (D. Minn. 1993). 
Entity law serves its traditional objectives well when it shields public investors from the debts of the parent corporation of the world's great enterprises in which they have invested. However, this is no longer the case when it shields the parent corporation from liability for the acts of its subsidiaries, and each subsidiary from liability for the acts of its sub-subsidiaries.

Entity law shapes the doctrines of procedure as well as the law of substantive liability. As this paper has attempted to demonstrate, doctrines grounded on entity law in the area of in personam jurisdiction, forum non conveniens, and perhaps joinder create procedural barriers of great magnitude to efforts to obtain a hearing in the United States of cases involving international human rights. This has the unhappy consequence that as far as the judicial system is concerned, American multinational corporations are not fully accountable for their conduct abroad. 
